\title{
The Rotterdam Study: 2010 objectives and design update
}

\author{
Albert Hofman - Monique M. B. Breteler · Cornelia M. van Duijn · \\ Harry L. A. Janssen - Gabriel P. Krestin - Ernst J. Kuipers · \\ Bruno H. Ch. Stricker · Henning Tiemeier · André G. Uitterlinden • \\ Johannes R. Vingerling · Jacqueline C. M. Witteman
}

Received: 30 July 2009/Accepted: 19 August 2009/Published online: 2 September 2009

(C) The Author(s) 2009. This article is published with open access at Springerlink.com

\begin{abstract}
The Rotterdam Study is a prospective cohort study ongoing since 1990 in the city of Rotterdam in The Netherlands. The study targets cardiovascular, endocrine, hepatic, neurological, ophthalmic, psychiatric and respiratory diseases. As of 2008, 14,926 subjects aged 45 years or over comprise the Rotterdam Study cohort. The findings of the Rotterdam Study have been presented in close to a 1,000 research articles and reports (see www.epib.nl/rotterdam study). This article gives the rationale of the study and its design. It also presents a summary of the major findings and an update of the objectives and methods.
\end{abstract}

Keywords Biomarkers - Cardiovascular diseases · Cohort study · Endocrine diseases · Epidemiologic methods · Genetic epidemiology · Liver diseases . Neurological diseases - Ophthalmic diseases . Pharmacoepidemiology · Psychiatric diseases . Respiratory diseases

A. Hofman $(\bowtie) \cdot$ M. M. B. Breteler · C. M. van Duijn ·

B. H. Ch. Stricker - H. Tiemeier - A. G. Uitterlinden ·

J. R. Vingerling - J. C. M. Witteman

Department of Epidemiology, Erasmus Medical Center, PO Box 2040, 3000 CA Rotterdam, The Netherlands

e-mail: a.hofman@erasmusmc.nl

H. L. A. Janssen - E. J. Kuipers - B. H. Ch. Stricker ·

A. G. Uitterlinden

Department of Internal Medicine, Erasmus Medical Center,

Rotterdam, The Netherlands

G. P. Krestin

Department of Radiology, Erasmus Medical Center,

Rotterdam, The Netherlands

J. R. Vingerling

Department of Ophthalmology, Erasmus Medical Center,

Rotterdam, The Netherlands

\section{Introduction}

The Rotterdam Study was designed in the mid-1980s as a response to the demographic changes that were leading to an increase of the proportion of elderly people in most populations [1]. It was clear that this would produce a strong rise in elderly people living with diseases, as most diseases cluster at the end of life, and that to discover the causes of diseases in the elderly one would have to study risk factors of those diseases [2]. A major approach to finding causes is the prospective follow-up study, which has proven quite effective in finding causes of heart disease and cancer.

\section{The design of the Rotterdam Study}

The basic design of the study is straight-forward: a prospective cohort study among, initially, 7,983 persons living in the well-defined Ommoord district in the city of Rotterdam in The Netherlands (78\% of 10,215 invitees). They were all 55 years of age or over and the oldest participant at the start was 106 years [3, 4]. The study started with a pilot phase in the second half of 1989. From January 1990 onwards participants were recruited for the Rotterdam Study. Figure 1 gives a diagram of the various cycles in the study.

In 1999, 3,011 participants (out of 4,472 invitees) who had become 55 years of age or moved into the study district since the start of the study were added to the cohort.

In 2006 a further extension of the cohort was initiated in which 3,932 subjects were included, aged 45-54 years, out of 6,057 invited, living in the Ommoord district. By the end of 2008, the Rotterdam Study therefore comprised 14,926 subjects aged 45 years or over. The overall response figure 


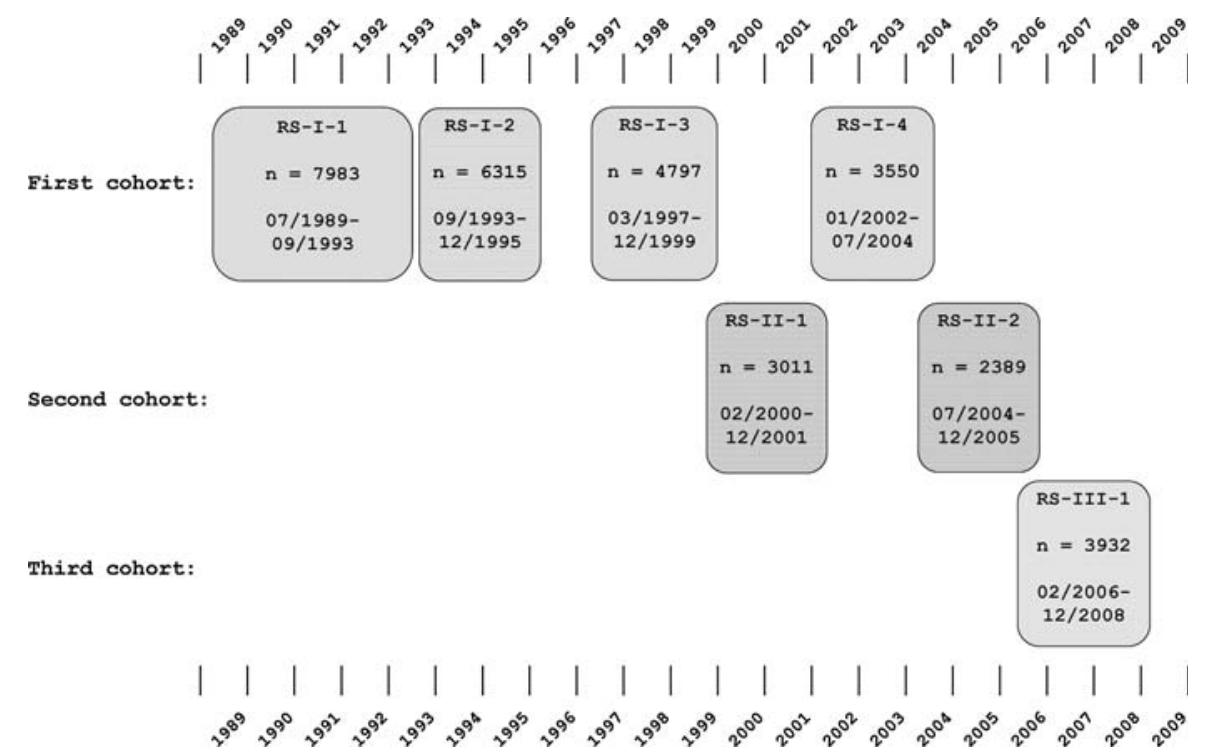

Fig. 1 Diagram of examination cycles of the Rotterdam Study $(R S)$. RS-I-1 refers to the baseline examination of the original cohort (pilot phase 07/1989-12/1989; cohort recruitment 01/1990-09/1993). RS-I-2, RS-I-3 and RS-I-4 refer to re-examination of the original cohort members. RS-II-1 refers to the extension of the cohort with persons in the study district that became 55 years since the start of the study or

for all three cycles at baseline was $72.0 \%$ (14,926 of 20,744).

The participants were all examined in some detail at baseline. They were interviewed at home $(2 \mathrm{~h})$ and then had an extensive set of examinations (a total of $5 \mathrm{~h}$ ) in a specially built research facility in the centre of their district. These examinations focussed on possible causes of invalidating diseases in the elderly in a clinically state-ofthe-art manner, as far as the circumstances allowed. The emphasis was put on imaging (of heart, blood vessels, eyes, skeleton and later brain) and on collecting bodily fluids that enabled further in-depth molecular and genetic analyses. These examinations were repeated every $3-4$ years in characteristics that could change over time. And so we had examination cycles from 1990 to 1993, from 1993 to 1995 , from 1997 to 1999 , from 2000 to 2001, from 2002 to 2004 , from 2004 to 2005 and from 2006 to 2008 (Fig. 1). In 2009 a new examination cycle started (RS-I-5).

The participants in the Rotterdam Study are followed for a variety of diseases that are frequent in the elderly (and many are also in the not so elderly): coronary heart disease, heart failure and stroke, Parkinson disease, Alzheimer disease and other dementias, depression and anxiety disorders, macular degeneration and glaucoma, respiratory diseases, liver diseases, diabetes mellitus and osteoporosis.

The Rotterdam Study has been approved by the institutional review board (Medical Ethics Committee) of the Erasmus Medical Center and by the review board of The Netherlands Ministry of Health, Welfare and Sports. those of 55 years or over that migrated to the study district. RS-II-2 refers to the re-examination of the extension cohort. RS-III-1 refers to the baseline examination of all persons aged 45 years and over living in the study district that had not been examined (i.e., mainly comprising those aged $45-55$ years)

The approval has been renewed every 5 years, as well as with the introduction of major new elements in the study (e.g., MRI investigations).

In the remainder of this article the objectives and major findings will be presented with an update of the methods for cardiovascular diseases, endocrine diseases, liver diseases, neurological diseases, ophthalmic diseases, psychiatric diseases, respiratory diseases, as well as for genetic and biomarker studies and for pharmaco-epidemiologic studies. For relevant recent EJE references see [5-27].

\section{Cardiovascular diseases}

\section{Objectives}

Research on the epidemiology of cardiovascular diseases focuses on three primary areas of interest: studies on risk factors for atherosclerosis and coronary heart disease, studies on the detection of subjects at high risk of coronary heart disease, and studies on cardiovascular conditions at older age.

Three groups of putative risk factors for atherosclerosis and coronary heart disease are included. The first are endocrine factors, including diabetes, insulin and insulin-like growth factor I, estrogens and androgens, and thyroid gland and adrenal gland hormones. The second group contains factors involved in hemostasis, inflammation and endothelial function. The third group, and currently a major focus, 
covers genetic factors in these areas in relation to risk of atherosclerosis and heart disease.

The ability of classical cardiovascular risk factors to identify subjects at high risk of coronary heart disease is limited. Risk stratification may be improved when based on the presence of atherosclerosis. To this end, repeated measurements of non-coronary atherosclerosis and measurements of coronary, carotid and aortic arch calcification have been included in the study.

Another line of research focuses on cardiovascular diseases in the elderly that are in large part the consequence of ischemic heart disease, like heart failure and atrial fibrillation. An important topic in this area is the early diagnosis of heart failure using echocardiographic assessment of asymptomatic systolic and diastolic dysfunction of the left ventricle. Atrial fibrillation is another major chronic condition frequent at older age. Examination of the determinants and prognosis of atrial fibrillation is part of this research line.

\section{Major findings}

Recent findings include the association between structural and diastolic echocardiographic parameters and all-cause mortality in individuals initially free of myocardial infarction, heart failure, atrial fibrillation, or atrial flutter [28]. The study found that gender differences in atherosclerosis are larger in coronary vessels than in carotid, aortic, or lower extremity vessels [29]. The insertion/deletion polymorphism of the angiotensin converting enzyme gene was found to be associated with increased mean changes of systolic blood pressure and pulse pressure [30].

We studied the validity of the Framingham Points Scores in our population and found that they perform reasonably well in elderly women, but need recalibration in elderly men [31]. The study showed that C-reactive protein (CRP) levels are associated with the extent and progression of ankle-brachial-index and carotid plaques and, albeit less pronounced, with aortic calcification and intima-media thickness [32].

The study enabled accurate assessment of the incidence and lifetime risk of heart failure and atrial fibrillation in an elderly population $[33,34]$. It was shown that inflammation is associated with heart failure [35]. Subclinical atherosclerosis, cigarette smoking and high-normal thyroid function were identified as new risk factors of atrial fibrillation [36-38].

The study showed that serum CRP is associated with the risk of type 2 diabetes independent of obesity. Moreover, genetic variants in the CRP gene were associated with the risk of diabetes [39]. The study showed that subjects with higher levels of serum uric acid have an increased risk of developing type 2 diabetes [40]. In collaborative work with the Framingham Heart Study, we identified 3 genetic loci associated with uric acid concentration and gout [41]. In a large collaborative consortium, the CHARGE consortium, we identified a significant association between chronic kidney disease and the UMOD gene which encodes TammHorsfall protein [42]. In the same consortium, we found four genes for systolic blood pressure, six for diastolic blood pressure and one for hypertension, as well as 1 genetic locus associated with variation in left ventricular diastolic dimensions and five loci associated with aortic root size [43, 44].

\section{Methods update}

Repeated measures of non-coronary atherosclerosis include carotid intima-media thickness and plaques by ultrasound and the ankle-arm index [45]. In previous examinations, electron-beam CT and, more recently, multi-detector CT were used to accurately quantify calcification in the coronary, aortic arch and carotid arteries [46]. Measurement of plaque vulnerability with high-resolution MRI of the carotid arteries started in October 2007 and will be continued. Other outcome measures include electrocardiography, echocardiography and abdominal aortic diameter measured by ultrasound [28]. In addition to repeated measures of structural and functional parameters of the left ventricle and atrium, measurements of structure and function of the right side of the heart will be performed.

Determinants are assessed by physical examinations, collection of blood samples, and by questionnaires and interview. The role of genetic factors and gene-environment interactions is studied using the candidate gene approach and more recently genome wide association studies, in which our data are often combined with those from other studies in the context of the large collaborative CHARGE consortium [47].

Clinical cardiovascular outcomes are collected during our continuous follow-up and include non-fatal myocardial infarction and cardiac death, revascularisations, heart failure, atrial fibrillation, gout, kidney failure, complications of diabetes and pulmonary hypertension [33, 34, 41, 42, 48]. For additional EJE references concerning cardiovascular disease see [49-67].

\section{Endocrine diseases}

\section{Objectives}

The main objective of the programme of endocrine epidemiology research is to study frequency and etiology of major disorders of the endocrine glands (pituitary, reproductive, thyroid, parathyroid, adrenal, and neuro-endocrine 
pancreas) and the musculoskeletal system. These include endocrine and locomotor diseases, including diabetes mellitus, osteoporosis, osteoarthritis, growth-hormone deficiency, hypo- and hyper-thyroidism and parathyroidism. The evaluation of risk factors for the above mentioned conditions includes serum measurements (such as classical hormones and other endocrine molecules) and genetic determinants of endocrine factors and signalling pathways.

\section{Major findings}

We have provided epidemiological documentation on the hormone, growth factor and biomarker profiles in the general population and determined the association with several diseases. Within the topics of locomotor diseases and disability we have reported that heart failure, COPD, diabetes mellitus and chronic disorders leading to locomotor complaints, are risk factors which contribute considerably to locomotor disability $[68,69]$.

In relation to osteoporosis we have determined the incidence of vertebral [70] and non-vertebral fractures [71], and the relationship between bone mineral density (BMD), BMD change and the occurrence of fracture [71], as well as with heel ultrasound measurements [72] and bone resorption markers [73]. We have also studied the relation between endogenous sex hormones and their binding factors, with fractures [74], and showed that increased homocysteine levels are a strong and independent risk factor for osteoporotic fractures [75]. We studied the relations between osteoporosis and other chronic diseases like osteoarthritis [76], cancer [77], atherosclerosis [78] and diabetes [79, 80], and provided indications for the treatment and diagnosis of osteoporosis. Lastly, we were part of several large consortia studying epidemiological risk factors for osteoporosis [81-83]. For osteoarthritis (OA) we have shown how a new marker of disease (CTX-II), is associated with the prevalence and the progression of radiographic OA [84], independent of known clinical risk factors. In addition, we have studied different aspects of OA disease definition and classification [85], evaluation of disease progression [86] and determined the most prominent risk factors leading to OA [87, 88].

We have also studied inflammatory aspects of endocrine diseases like diabetes mellitus [89], and the relations of hypo/hyperthyroidism to cardiovascular and neurological disease [90]. We further examined the influence of genetic variation in endocrine genes influencing hormone levels [91], interaction of genetic factors in relation to fracture risk [92, 93], to cardiovascular risk factors [94] and to neurological conditions [95]. Our team has played a leading role in bringing together the global GENOMOS consortium which has performed prospective meta-analyses across many epidemiological cohorts for the most prominent candidate genes for osteoporosis (see also Genetic and biomarker studies).

\section{Methods update}

For all participants DXA-based BMD measurements of the lumbar spine, dual hip and total body BMD, as well as determination of body composition parameters are assessed with a Prodigy ${ }^{\mathrm{TM}}$ total body fan-beam densitometer (GE Lunar Corp, Madison, WI, USA). Hip structural analysis [96] of DXA scans is available in a subset of participants, while hip strength indexes (software by GE Lunar) are determined for all scans. In the current follow-up cycle we have introduced since 2009 iDXA measurements (GE Lunar) which performs lumbar spine, dual hip and total body scans. Measurements include L1-L4 BMD, bilateral total hip and femoral neck BMD and total body BMD. From the total body scan, we measure lean mass and fat mass body composition, including total body, trunk, arm, legs, and android and gynoid regions of interest.

$\mathrm{X}$-ray examinations of vertebral bodies, hips, knees and hand/wrist are obtained by a digitalized Fuji FCR system (FUJIFILM Medical Systems) and assessed for the presence of fractures and/or degenerative changes of the joints. Vertebral fractures are assessed using the qualitative algorithm-based technique termed the ABQ method, an update to the quantitative McCloskey-Kanis method [97]. Incident clinical fractures are obtained from computerized records of the general practitioners and hospital registries which are regularly checked by research physicians who review and code the fracture information. Muscle strength is assessed in all participants with a hand grip dynamometer.

The incidence and progression of $\mathrm{OA}$ is done using Kellgren scores obtained from X-rays of hip, knee, hands, en spine. The complete set of X-rays is also available in digitized form. Novel diagnostic assessments for OA are currently underway using Magnetic Resonance Imaging (MRI) on a large subset of the population. Several specific biomarker assessments in blood/serum/plasma and urine are done for the diagnosis and evaluation of risk factors of endocrine and metabolic diseases.

Candidate gene and genome-wide association studies (GWAs) are actively pursued within the scope of our research for many of the above mentioned endocrine and locomoter traits and diseases. Finally, validated questionnaires evaluating nutrient intake (e.g., calcium and vitamins) and activities of daily living, allow to evaluate the role of environmental factors in endocrine conditions and locomotor diseases of the elderly. For recent references in EJE see [98-104]. 


\section{Liver diseases}

\section{Objectives}

The objectives are to study the prevalence and incidence of liver disease, as well as to investigate the role of genetic and environmental determinants. The focus will be on liver fibrosis and steatosis. Fibrinogenesis of the liver is most probably not only the result of well known liver diseases, such as viral hepatitis, alcoholic liver disease or nonalcoholic fatty liver disease (NAFLD), but rather a complex interaction between a genetic predisposition and these liver disorders. Hepatologic focus in the Rotterdam Study will be on the association between these known causes of liver disease and the occurrence, magnitude, and progression of fibrosis in combination with genetic and environmental effect modifiers. The incidence of steatosis in this population will also be studied. Steatosis of the liver is the hepatic manifestation of the metabolic syndrome (type 2 diabetes, abdominal obesity, dyslipidemia and arterial hypertension) with interesting relations to other scientific research topics in the Rotterdam Study.

\section{Abdominal ultrasound}

As of February 2009, trained technicians perform abdominal ultrasonography in all RS-I-5 participants. Liver, biliary tract, gall bladder, spleen, pancreas, and kidneys in combination with Doppler examination of hepatic veins, hepatic artery and portal vein will be evaluated. All images are stored digitally and will be reevaluated by a physician with expertise in hepatic ultrasonography.

\section{Assessment of steatosis}

\section{Hepatic ultrasonography}

The diagnosis of liver steatosis will be based on evident ultrasonographic contrast between the hepatic and right renal parenchyma (high-level echoes arising from the hepatic parenchyma). Steatosis will be graded on a threegrade scale (none, mild and severe) [105].

\section{Assessment of fibrosis}

\section{Hepatic ultrasonography and elastography}

Ultrasonographic evaluation of the liver parenchyma and liver surface will be performed in order to assess severe fibrosis and/or cirrhosis. Additionally sonographic signs of portal hypertension will be studied (splenomegaly, venous collaterals, portal vein diameter and flow, hepatic venous flow, and the presence of ascites).
To assess and quantify the grade of fibrosis, trained technicians will perform elastography in all participants. This test measures non-invasively and quantitatively the liver stiffness using a probe which includes an ultrasonic transducer transmitting a vibration wave through the liver. The velocity of the ultrasonic wave correlates directly with tissue stiffness [106, 107].

\section{Determinants of interest}

The association between genetic and environmental factors known to influence liver function and the occurrence of steatosis and fibrosis will be studied. Additionally, the association of these conditions with numerous determinants will be studied such as, for example, age, gender, food intake, concurrent alcohol intake, risk factors for viral hepatitis, BMI, waist-to-hip ratio, serum glucose and diabetes mellitus, serum cholesterol and triglycerides, insulin like growth factor (IGF), C-reactive protein and interleukins. All clinical information will be obtained by interview (updated with liver specific questions) and clinical examination.

\section{Neurological diseases}

\section{Objectives}

Neuroepidemiologic research in the Rotterdam Study focuses on the frequency, etiology and early recognition of the most frequent neurologic diseases in the elderly, including dementia, in particular Alzheimer disease, Parkinson disease and stroke. In neurodegenerative and cerebrovascular disorders clinical symptoms typically become manifest late in the disease course, the occurrence of clinical disease does not reflect the underlying spectrum of disease-related pathology, and most of the clinical syndromes are etiologically heterogeneous. Therefore, an additional research focus is on the causes and consequences of pre-symptomatic brain pathology that can be assessed with non-invasive imaging modalities.

\section{Major findings}

Neurodegenerative and cerebrovascular diseases are highly frequent in the elderly. The prevalence increases from age 55 to 65 years to age 90 years and above from less than $1 \%$ to over $40 \%$ for dementia [108], from less than $0.5 \%$ to more than $4 \%$ for Parkinson disease [109], and from approximately $1 \%$ to nearly $10 \%$ for stroke. The incidence figures follow this pattern of a strong increase with age over the entire age range, with the age-specific incidence of dementia being identical for men and women at least until 
the age of 85 [110] but with men having a higher agespecific incidence of both stroke and Parkinson disease than women throughout the age range $[111,112]$.

Vascular pathology and vascular risk factors are associated with worse cognitive performance [113], which also translates in people with vascular pathology or risk factors for vascular disease having an increased risk of dementia, including Alzheimer disease [114]. Moreover, several life style factors are associated with the risk of dementia and Alzheimer disease [115-117], suggesting that onset of dementia may at least partly be delayed or prevented. Commonly used drugs may have a role in this [118].

The classical risk factors for stroke also predict risk of stroke in the Rotterdam Study [119]. More recently identified risk factors, including inflammatory markers, may be etiologically relevant but thus far add little to the identification of people at risk [120]. Possibly underlying this is that a large amount of stroke goes clinically undetected [121]. Nearly $20 \%$ of elderly people have at least one silent brain infarct, and thereby a nearly fourfold increased risk of clinical stroke, a more than doubled risk of dementia including Alzheimer disease, and an increased risk of depression [121].

Neuroimaging reveals that brain pathology is widespread [122] and can go clinically undetected for a long time. In addition to the silent infarcts, many apparently healthy elderly have ischemic changes in their cerebral white matter that are associated with an increased risk of dementia, stroke and depression. Also brain atrophy, especially of the hippocampus, is already present years before onset of even the earliest sign of cognitive impairment or subjective complaints. This emphasizes the need to shift the attention in etiologic research of neurodegenerative and cerebrovascular disease to the causes of pre-symptomatic and underlying brain changes. Technological advances in image acquisition, optimized imaging sequences and automated post-processing of multispectral MR data are major drivers of the rapid developments in this field. The 3D T2* GRE sequence that we use was specifically developed to increase the conspicuity of cerebral microbleeds [123]. With this optimized sequence, we found that microbleeds were present in nearly $20 \%$ of persons over the age of 60 years, mounting to a prevalence of over 1 in 3 in persons aged 80 years and older; a much higher prevalence than was reported hitherto [124]. Moreover, we found supportive evidence that deep or infratentorial microbleeds reflect arteriolosclerotic angiopathy, whereas strictly lobar microbleeds are caused by cerebral amyloid angiopathy. These findings impact research into the causes of cerebral amyloid angiopathy, as well as fuel the ongoing discussion about the safety of antithrombotic therapy in persons with microbleeds [125]. Diffusion tensor imaging (DTI) allows the assessment of the microstructural integrity of white matter. White matter microstructure looses its integrity with increasing age, but this can largely be explained by presence of white matter atrophy and white matter lesions [126]. Nevertheless, the microstructural integrity in the normal appearing white matter and in white matter lesions relates to cognitive function regardless of concurrent macrostructural changes, emphasizing the importance of the microstructural integrity of white matter [127].

Methods update

Assessment of dementia and Alzheimer disease

In the baseline and follow-up examinations participants undergo an initial screen for dementia with the Mini Mental State Examination (MMSE) and the Geriatric Mental Schedule (GMS), followed by an examination and informant interview with the Cambridge Examination for Mental Disorders of the Elderly (CAMDEX) in screenpositives (MMSE $<26$ or GMS $>0$ ), and subsequent neurological, neuropsychological and neuroimaging examinations [108, 110]. Of subjects who cannot be reexamined in person, information is obtained from the GPs and the regional institute for outpatient mental health care. A consensus panel makes the final diagnoses in accordance with standard criteria (DSM-III-R criteria; NINCDS-ADRDA; NINDSAIREN).

\section{Assessment of Parkinsonism and Parkinson disease}

Participants are screened in the baseline and follow-up examinations for cardinal signs of parkinsonism (resting tremor, rigidity, bradykinesia, or impaired postural reflexes). Persons with at least one sign present are examined with the Unified Parkinson's Disease Rating Scale and a further neurologic exam. PD is diagnosed if two or more cardinal signs are present in a subject not taking antiparkinsonian drugs, or if at least one sign has improved through medication, and when all causes of secondary parkinsonism (dementia, use of neuroleptics, cerebrovascular disease, multiple system atrophy, or progressive supranuclear palsy) can be excluded [109, 112].

\section{Assessment of stroke and stroke subtypes}

History of stroke at baseline was assessed through interview and verified in medical records. Putative incident strokes get identified through the linkage of the study database with files from general practitioners, the municipality, and nursing home physicians' files, after which additional information (including brain imaging) is collected from hospital records. A panel discusses all potential strokes and subclassifies strokes into ischemic, hemorrhagic or unspecified $[111,120]$. 
Assessment of cognitive function

Global cognitive function is measured through the Mini Mental State Examination (MMSE) in all surveys. From the third survey (RS-I-3) onwards we added a $30 \mathrm{~min}$ test battery that was designed to assess executive function and memory function, and which includes a Stroop test, a Letter Digit Substitution Task, a Word Fluency Test, and a 15 words Word List Learning test.

\section{Rotterdam Scan Study: brain imaging within the Rotterdam Study}

In 1991, a random sample of 111 participants underwent axial T2-weighted magnetic resonance (MR) imaging to assess presence and severity of white matter lesions [128]. In 1995, a random sample of 563 non-demented participants underwent brain MR imaging in the context of the Rotterdam Scan Study. The scanning protocol included series of axial proton-density, T2-weighted and T1-weighted images, as well as a high-resolution 3D-HASTE sequence [129]. From August 2005 onwards, a dedicated 1.5 Tesla scanner is operational in the research center of the Rotterdam Study, and brain imaging is performed in all study participants without contra-indications. The scanning protocol includes 4 high-resolution axial sequences (3D T1-weighted; 2D PD-weighted; 2D FLAIR; and 3D T2* GRE), 2D phasecontrast imaging, and diffusion tensor imaging (DTI).

\section{Ophthalmic diseases}

\section{Objectives}

The ophthalmic part of the Rotterdam Study focuses on frequency and risk factors of chronic ophthalmic diseases and on ophthalmological characteristics of systemic diseases in the elderly. Emphasis is laid on age-related macular degeneration, open angle glaucoma, retinal vessel diameters and, recently, myopia and other refractive abnormalities.

\section{Major findings}

Age-related macular degeneration (AMD)

AMD prevalence increased exponential with age [130] and AMD was the main cause of blindness in the high age-group [131]. Risk factors that were found for AMD are smoking, atherosclerosis, hyperopia [132-134]. The APO-E $\varepsilon-4$ allele showed an inverse association with AMD [135]. First-degree relatives of patients with late ARM developed ARM at an increased rate at a relatively young age [136]. The heterogeneity of genetic risk among AMD families is considerable, and the proportion of high-risk families is relatively small $[137,138]$. The anticipated protective effect of statins on AMD could not be substantiated in participants of the Rotterdam Study [139, 140]. A high dietary intake of beta carotene, vitamins $\mathrm{C}$ and $\mathrm{E}$, and zinc was associated with a substantially reduced risk of AMD [141]. Alcohol consumption was not a risk factor for AMD [142]. The CFH $\mathrm{Y} 402 \mathrm{H}$ polymorphism accounted for a substantial proportion of AMD cases in the Rotterdam Study and particularly in the presence of environmental and genetic stimulators of the complement cascade [143, 144]. Three common SNPs in the VEGF gene were not associated with AMD [145]. Cataract surgery increased the risk of dry AMD, particularly in homozygous CFH Y402H carriers [146]. Lipoprotein-associated phospholipase A2 levels were not an important risk factor for AMD despite the partly inflammatory pathogenesis of AMD [147].

\section{Open angle glaucoma $(O A G)$}

The prevalence of OAG was highly dependent on the applied criteria. That was a major reason for proposing a classification system without final, subjective adjudication [148]. Systemic blood pressure and hypertension were associated with elevated intraocular pressure but not with prevalent OAG. Relatives of patients with OAG had a strongly increased risk of glaucoma. Enlarged cup-disc ratio was the earliest and most prominent feature of familial aggregation. The incidence of OAG rose with increasing age, most of these patients were unaware of having OAG. The incidence of visual field loss rises fivefold between 55 and 80 years in the general population. Glaucoma is the main cause for visual field loss, followed by stroke. Atherosclerosis, serum CRP level and diabetes mellitus were not a risk factor for OAG. Calcium channel antagonists were associated with open-angle glaucoma in Rotterdam Study participants. These results do not support the use of calcium channel antagonists for the treatment of normal-tension glaucoma. Polymorphisms in the estrogen receptor beta genes were associated with an increased risk of OAG in men. Use of topical beta-blockers seems not to be associated with excess mortality. We estimated that in a white population with a low prevalence of pseudoexfoliation, about one in 1,000 persons screened with a periodic OAG screening program could be saved from bilateral endstage OAG.

\section{Retinal vessel diameters}

Larger retinal venular diameters were associated with generalized atherosclerosis, inflammation and cholesterol levels and may play their own independent role in predicting cardiovascular disorders [149]. Larger retinal 
venular diameters were related to incident stroke and cerebral infarction [150], progression of cerebral small vessel disease [151] and incident impaired glucose tolerance and diabetes mellitus [152]. Smaller retinal artery diameters were related to incident hypertension [153].

\section{Methods update}

At baseline and follow-up examinations participants undergo ophthalmic measurements including best corrected ETDRS visual acuity, refractive error, Goldmann applanation tonometry, keratometry, slitlamp examination of the anterior segment and visual field testing. In pharmacological mydriasis we made $35^{\circ}$ color photographs of the macular area, and $20^{\circ}$ simultaneous stereoscopic imaging of the optic disc and macular area. Analog fundus photography was replaced by stereoscopic digital imaging of the macular area and optic disc since the third follow-up examination. Optic nerve head analysis with a Heidelberg Retina Tomograph, macular pigment density, and melanin optical density measurements were added during the third follow-up (RS-I-3). Fourier domain optical coherence tomography of the macular area and optic disc, axial-length and fundus autofluorescence measurements were added at the fifth follow-up examination (RS-I-5).

\section{Assessment of AMD}

To diagnose $\mathrm{AMD}, 35^{\circ}$ color photographs were taken of the macular area of each eye at each follow-up examination after pharmacologic mydriasis. The images were graded with $12.5 \times$ magnification according to the International Classification and Grading System for age-related maculopathy [154].

\section{Assessment of $O A G$}

At baseline and follow-up, identical ophthalmic examinations on each eye were performed that consisted of Goldmann applanation tonometry, visual field screening and ophthalmoscopy, and stereoscopic fundus photography with pharmacologic mydriasis. OAG was diagnosed using an algorithm for the diagnosis of OAG based on presence or absence of glaucomatous optic neuropathy (GON), glaucomatous visual field loss, or both, yielding a classification as no, possible, probable, or definite OAG [148].

\section{Assessment of retinal vessel diameters}

Vessel measurements were performed on digitized fundus color transparencies of the optic disc. For each subject, the image with the best quality was analyzed with a semiautomated system. Vessel measures were computed using the improved Parr-Hubbard formula, adjusted for magnification errors [149].

\section{Psychiatric diseases}

\section{Objectives}

The aim of the programme of psychiatric research in the Rotterdam Study is to investigate the determinants, correlates and consequences of common psychiatric problems. The focus has been on depressive disorders, but anxiety disorders, sleep disturbances, addiction to smoking, and complicated grief are also being studied.

Major findings

\section{Depression}

Recently we completed our study of the incidence and recurrence of depression [155]. During the follow-up period of 8 years on average, 566 depressive syndromes and 1,073 episodes of clinically relevant depressive symptoms occurred. For depressive syndromes, the incidence rate was 7.0 (95\% CI: 6.0-8.3) per 1,000 person-years and the recurrence rate was 27.5 (95\% CI: 23.7-32.1) per 1,000 person-years. The incidence and recurrence rates more than doubled when episodes of depressive symptoms were included. The recurrence rate of depressive syndromes was equal for women and men, but all other rates were almost twice as high for women compared with men. The rates did not seem to change with age.

In a series of studies we found some evidence for the vascular depression hypothesis. More severe coronary and extra-coronary atherosclerosis were associated with a higher prevalence of depression, as were cerebral haemodynamic changes [156, 157]. However, we could not rule out that earlier depressive episodes may have contributed to the development of atherosclerosis. Moreover, our data did not support a specific symptom profile of vascular depression as previously defined [158].

\section{Sleep}

We investigated the relationships of sleep duration with both cardiovascular risk factors and psychiatric disorders. We found a marked $U$-shaped association of actigraphically measured total sleep time with BMI and obesity [159]. Sleep fragmentation also increased the likelihood of a higher BMI and obesity, although, in the very old sleep fragmentation is a risk factor for low cholesterol levels [160]. Self-reported total sleep time was also examined in relation to depressive disorders and anxiety disorders in more than 5,000 persons 
[161]. Again, both short and long sleepers were more likely to be depressed or to have an anxiety disorder than persons with a total sleep time of 7-8 h.

\section{Anxiety}

We found that prevalent anxiety disorders fulfilling DSM-IV criteria may be much less co-morbid with depressive disorders than previously thought if the disorders are assessed with different diagnostic instruments. On the other hand, a history of depression is very common in persons with prevalent anxiety disorder (more than $50 \%$, unpublished data).

\section{Smoking}

Typically, determinants of smoking cessation are studied by comparing former with current smokers. We recently introduced a prospective approach of studying smoking cessation in 1,200 smokers (mean years of smoking: 40 years, minimum: 10 years). Smoking status was repeatedly assessed during follow-up every 3- to 4-years. In all examination rounds participants were asked whether they still smoked and if not, when they had stopped. Thus, an individual could contribute any number of person-years (maximum 14 person-year) to the analyses. In other words, people were classified as smokers or quitters on a day-by-day basis. This approach enabled us to detect genetic effect on the incidence of smoking cessation [162].

\section{Genetics of common psychiatric disorders}

Several SNPs have been investigated as potential determinants of depression, mostly with negative results. However, we found that an ER-alpha polymorphism had a substantial effect on anxiety but not on depression in women [163]. In the past year, we have performed a series of genome-wide association studies of the above psychiatric and psychological phenotypes, mostly as part of the CHARGE consortium [47]. Whereas several analyses have yielded no convincing genome wide significant resultspossibly because initial studies were underpowered, psychiatric phenotypes do not present very homogenous entities, or are highly poly-genetic-the genome wide analyses of the intermediate phenotype cortisol is more promising. Replication in other general population studies and genetic isolate studies is attempted and may yield new candidate genes for psychiatric disorders.

Finally, ongoing psychiatric research projects examine whether and how psychological well-being or psychiatric problems contribute to survival. Most importantly, we are interested in whether the effects are independent of confounding by physical disease or can be explained by lifestyle, immunological or hormonal regulation.
Methods update

In the first years of the Rotterdam Study I (RS-I-1, see Fig. 1) psychiatric data collection was very limited. In the second visit (RS-I-2) most participants were screened for depressive symptoms and from the third examination (RS-I-3) onwards, which began in 1997, depressive symptoms and disorders are have been ascertained in all participants. An assessment of anxiety disorders, sleeping disturbances and complicated grief were added in the fourth examination (RS-I-4) and have been included in all follow-up visits of the Rotterdam Study I and II cohorts, and in the baseline of the Rotterdam Study III cohort.

\section{Major determinants}

Psychiatric research in the Rotterdam Study focuses on biological risk factors. The vascular depression hypothesis was tested with different measures of atherosclerosis, arterial stiffness and cerebral blood flow [156]. We also examined whether blood levels of vitamins and fatty acids, immune parameters, and markers of folate metabolism increased the likelihood of depression [157, 164, 165]. In one ongoing project, diurnal patterns of cortisol secretion are related to psychiatric and other disorders such as subclinical atherosclerosis [166]. Studies of genetic polymorphisms and brain morphology are underway [167]. Current data collection includes a dexamethasone suppression test to measure hypothalamic-pituitary-adrenal axis activity in all participants, which is unique in a population-based study. Also, psychiatric problems and psychological traits such as happiness, sleep duration and depression are increasingly studied as determinants of health and mortality [168].

\section{Major outcomes}

Information on depression is obtained from (a) psychiatric examinations, (b) self-reported histories of depression, (c) medical records, and (d) registration of antidepressant use [155]. The psychiatric examination during follow-up visits consists of a screening with the Center for Epidemiologic Studies Depression Scale (CES-D), and in the screen-positive participants a semi-structured interview performed by a trained clinician [169]. The self-reported history of depression includes standardized questions to ascertain whether participants had experienced a depressive episode, and if they had been treated. In order to continuously monitor incidence of depression throughout follow-up, trained research-assistants scrutinize the medical records of the general practitioners (GPs) and copy the information about a potential depression.

The following anxiety disorders are assessed with a slightly adapted Munich version of the Composite 
International Diagnostic Interview: generalized anxiety disorder, specific and social phobia, agoraphobia without panic disorder, and panic disorder [161, 170].

Sleep quality and disturbance is measured with the Pittsburgh Sleep Quality Index. In addition, sleep duration and fragmentation are assessed with actigraphy, a method that infers wakefulness and sleep from the presence or absence of limb movement [171]. In total, nearly 2,000 persons participated in this actigraphy study: they wore an actigraph and kept a sleep diary for, on average, six consecutive nights.

The Inventory of Complicated Grief is used to identify traumatic grief [172]. This is a condition distinct from normal grief and bereavement-related depression, characterized by symptoms like disbelief about the death and searching for the deceased.

\section{Respiratory diseases}

\section{Objectives}

The objectives are to study the incidence of chronic obstructive pulmonary disease (COPD), to investigate genetic and environmental risk factors for COPD, and to study the effect of COPD on mortality. COPD is defined as a disease state characterized by airflow limitation that is not fully reversible. The airflow limitation is usually both progressive and associated with an abnormal inflammatory response of the lungs to noxious particles or gases such as tobacco smoke [173]. COPD is a worldwide leading and still increasing cause of chronic morbidity and mortality that will change from the sixth to the third most common cause of death worldwide by 2020, whilst rising from fourth to third in terms of morbidity [174].

\section{Major findings}

In the first cohort of the Rotterdam Study (RS-I) of 7,983 participants, 648 cases were identified with incident COPD after a median follow-up time of 11 years. This resulted in an overall incidence rate of 9.2/1,000 person-years (PY) (95\% CI, 8.5-10.0). The incidence rate of COPD was higher among men $(14.4 / 1,000 \mathrm{PY}$; 95\% CI, 13.0-16.0) than among women $(6.2 / 1,000 \mathrm{PY} ; 95 \% \mathrm{CI}, 5.5-7.0)$ and higher in smokers than in never-smokers $(12.8 / 1,000 \mathrm{PY}$; 95\% CI, 11.7-13.9 and 3.9/1,000 PY; 95\% CI, 3.2-4.7, respectively). Remarkable was the high incidence in the youngest females in the age category of 55-59 years (7.4/1,000 PY; 95\% CI, 4.1-12.6). For a 55 year-old man and woman, still free of COPD at cohort entry, the risk to develop COPD over the coming 40 years was 24 and $16 \%$, respectively [173].
Since COPD is not only affecting the lungs, but is also characterised by extrathoracic manifestations, another line of research focuses on the role of systemic inflammation in the pathogenesis of COPD and its comorbidities. High levels of hsCRP ( $>3 \mathrm{mg} / \mathrm{l})$, a marker of systemic inflammation, were associated with a significantly increased risk of incident COPD (hazard ratio (HR), 1.7; 95\% confidence interval (95\%CI), 1.16-2.49) compared with persons with low CRP levels $(<1 \mathrm{mg} / \mathrm{l})$. The risk remained increased after adjustment for potential confounders and introduction of a potential latency period of 3 years. The risk was most pronounced for former smokers (HR, 2.2; 95\% CI, 1.123.74). No CRP single nucleotide polymorphism or haplotype was associated with a significantly increased or decreased COPD risk [175].

Methods update

\section{Clinical assessment of COPD}

For the validation of the COPD cases, we had access to hospital discharge letters, files from the general practitioners, spirometry reports and pharmacy dispensing data for patients participating in the Rotterdam Study. Spirometry was performed in the context of the first Rotterdam cohort study (RS-I) in 3,550 participants. In addition, throughout the entire study period, spirometries were also performed on clinical indication by respiratory specialists and internists with a subspeciality in respiratory medicine. In the absence of spirometry, all medical information of subjects who used respiratory medication for at least 6 months and all hospital discharge letters or mortality reports with a coded diagnosis of COPD were reviewed. Definite COPD was defined by a moderate-to-severe obstructive spirometry $\left(\mathrm{FEV}_{1} / \mathrm{FVC}<0.7\right.$ and $\mathrm{FEV}_{1}<80 \%$ predicted), and/or as COPD diagnosed by a specialist in internal medicine (mainly respiratory physicians or internists with a subspeciality in respiratory medicine) based upon the combination of clinical history, physical examination and spirometry. Probable COPD was defined by a mild obstructive spirometry $\left(\mathrm{FEV}_{1} / \mathrm{FVC}<0.7\right.$ and $\mathrm{FEV}_{1} \geq 80 \%$ predicted $)$ and/or as COPD diagnosed by a physician in another medical speciality (e.g., a general practitioner).

Clinical outcomes are collected during our continuous follow-up and include respiratory and non-respiratory death, hospitalisations due to exacerbations of COPD as well as moderate to severe COPD exacerbations treated with systemic corticosteroids and/or antibiotics.

Pulmonary function testing

In the 5th round of the first cohort of the Rotterdam Study (RS-I-5), the 3rd round of the second cohort (RS-II-3), and 
the 2nd round of the third cohort (RS-III-2), more detailed and sophisticated techniques will be used to assess pulmonary function. Since COPD encompasses small airway disease (obstructive bronchiolitis) and parenchymal destruction of the lungs (emphysema), both components will be investigated by spirometry and measurement of pulmonary diffusion capacity, respectively.

\section{Spirometry}

Spirometry is performed by trained paramedical personnel using an electronic spirometer with pneumotachograph (Jaeger Masterscreen PFT, Cardinal Health, Hoechberg, Germany), according to the American Thoracic Society (ATS)/European Respiratory Society (ERS) guidelines. Forced expiratory volume in one second $\left(\mathrm{FEV}_{1}\right)$, forced vital capacity $(\mathrm{FVC})$ and $\mathrm{FEV}_{1} / \mathrm{FVC}$ ratio are measured; the spirogram (volume-time curve) and maximal expiratory flow-volume curve are also recorded. The interpretation of spirometries is performed independently by two research physicians; in case of discordance between both physicians, a senior respiratory physician decides.

\section{Measurement of pulmonary diffusion capacity}

Measurement of diffusion capacity by single-breath determination of carbon monoxide (CO) uptake in the lung (DL, CO) assesses the uptake of carbon monoxide (CO) from the lung over a breath-holding period [176]. The DL,CO is measured using the Jaeger Masterscreen PFT Pro Diffusion apparatus (Cardinal Health, Hoechberg, Germany) according to the guidelines of the ATS/ERS task force on standardisation of lung function testing [176]. The test gases used to calculate DL, CO include a tracer gas (methane), to measure alveolar volume $\left(V_{\mathrm{A}}\right)$, as well as carbon monoxide ( $\mathrm{CO} 0.3 \%)$. The remainder of the test gas mixture includes $\mathrm{O}_{2}$ and $\mathrm{N}_{2}$. For recent EJE references in this area see [177-184].

\section{Genetic and biomarker studies}

\section{Objectives}

The first objective of the laboratory team is to collect, store and manage the biological tissues mainly blood and urine sampled in the Rotterdam Study. The second objective of the group concerns genotyping and assessment of biomarkers.

Major findings

Among the biomarker analyses our study documenting the relationship between homocysteine and osteoporosis was novel [185] and has since been widely replicated. Across all research lines in the Rotterdam Study, several candidate gene studies have also yielded new insights coming from both exploratory studies as well as from collaborative replication efforts. A unique feature of the Rotterdam Study is exploited by studying the relationship between pleiotropic gene variants and multiple diseases and diseaserelated endpoints. For example, the studies on the promoter region of the IGF-1 gene revealed a series of consistent associations ranging from birth weight to diabetes [186], while other consistent associations involve the estrogen receptor alpha (ESR1) gene in relation to osteoporosis [187], osteoarthritis, height, myocardial infarction [188], age-at-menopause, and depression.

Rotterdam Study investigators are playing leading roles in the emerging large global consortia focussed on assessing the contribution of complex disease gene variants by prospective meta-analysis across many epidemiological cohorts [189], such as CHARGE, ENGAGE and the GENOMOS/GEFOS [190, 191]. Since 2005 the genome wide association study (GWAs) has changed the field of complex genetics, and identified an ever growing list of common variants contributing to disease risk and explaining genetic variance of traits. Initial findings in the Rotterdam Study from individual collaborations replicating early GWAs hits included CFH in age-related macula degeneration [143], NOS1AP in QT interval [192], and several SNPs involved in height, type 2 diabetes, and breast cancer (collaboration with WTCCC investigators).

The Rotterdam Study has generated GWAs data for almost the complete dataset summing to over 11,000 DNA samples, and is involved as a major collaborative centre for meta-analysis studies of GWAs data, including national programs (RIDE, NGI-NCHA), EU-funded projects (GEFOS, TREATOA, ENGAGE), and voluntary collaborations (GIANT, MAGIC, CHARGE). Especially, from the CHARGE consortium (the Rotterdam Study together with the Framingham Study, AGES, CHS, and ARIC) many important publications have emerged on a wide variety of phenotypes and diseases from all major research lines in the Rotterdam Study [193-196].

\section{Data collection, storage and management}

At each examination, blood, serum, plasma (citrate, heparine, and EDTA based), sputum, and urine are collected. Fasting blood samples are collected along with challenged samples as part of a glucose tolerance test. Sputum is collected before and after a dexamethasone-suppression test. Sputum is frozen at $-196^{\circ} \mathrm{C}$ before and after the challenge and stored at $-80^{\circ} \mathrm{C}$. To obtain serum and plasma, tubes are centrifuged according to a protocol standardising time and conditions from the drawing of blood to centrifugation. All 
samples are snap frozen at $-196^{\circ} \mathrm{C}$ using liquid nitrogen and stored at $-80^{\circ} \mathrm{C}$. RNA is isolated from blood within $5 \mathrm{~h}$ after sampling and stored at $-20^{\circ} \mathrm{C}$. DNA is isolated from blood and extraction has been recently automated using a Hamilton STAR pipetting platform and AGOWA magnetic bead technology. DNA sample storage is in Matrix 2D-barcode tubes in 96 well format. Overnight urine samples are collected, frozen at $-196^{\circ} \mathrm{C}$ and stored at $-80^{\circ} \mathrm{C}$. For data management, an in-house customized laboratory management system has been developed. Sample retrieval will be automated with an in-house customized laboratory track and trace system.

\section{Blood assessments}

For all participants, serum cholesterol, HDL, LDL, triglycerides, glucose and glucose levels are assessed. In urine, micro albumin and creatinine are determined in all participants. There have been a large number of specific blood/serum/plasma-based biomarker assessments, including steroids (e.g., estrogens, androgens, vitamin D, cortisol), interleukins, CRP, IGF1, insulin, iron-parameters (iron, ferritin and transferrin saturation), fibrinogen, homocysteine, folic acid, riboflavine, pyridoxine, SAM/ SAH ratio, cobalamine, Lp-PLA2, Fas/Fas-L, vitamins, abeta42/40 and thyroid hormones (TSH).

\section{Genotyping facilities}

Affiliated laboratory facilities include a medium/highthroughput platform for candidate gene studies and GWAs analyses. The facilities use high-end automated machinery including a Caliper/Zymark ALH 3000 pipetting robot (including a TwisterII, and integrated plate sealer, plate reader (OD 260/280), a Tecan EVO 150 Freedom pipetting robot, a Deerac Equator NS808 nanoliter liquid dispenser, 15 electronic PCR machines (ABI 9700, $2 \times 384$ ), an ABI7900HT Taqman machine (running $1 \mathrm{ng}$ gDNA in $2 \mu \mathrm{l}$ reactions), a WAVE 3500HT dHPLC, Sequenom iPlex, and two ABI3100 sequencing machines. DNA sample handling is centred on 384-well plates. Candidate gene studies are done mostly using Taqman and Sequenom genotyping with throughputs at 30,000 genotypes per day. Continuous efforts are focussed on reducing the required amount of genomic DNA which is now down to $1 \mathrm{ng}$ per genotype. GWAs genotyping studies are based on $500 \mathrm{~K}$ Affymetrix arrays (a pilot project of 450 women) and 550 and $610 \mathrm{~K}$ Illumina arrays for the complete Rotterdam Study cohort encompassing over 11,000 DNA samples. The in-house GWAs genotyping facility has been partly sponsored by NWO investment grants (911-03-012; 175.010.2005.011), is part of the Erasmus Medical Center Biomics core facility, and serves as knowledge center for polymorphism analysis attracting national and international interested parties, both academic and industrial.

\section{Candidate gene studies}

We have genotyped over 300 individual polymorphisms as part of candidate gene studies across the complete cohort and conducted a large number of candidate gene studies in the Rotterdam Study. These mostly concern individual potentially functional single nucleotide polymorphisms (SNPs) per gene, but sometimes also haplotype tagging SNPs (e.g., ESR1, ESR2, HSD11B1, fibrinogen), and also high density SNP screening (e.g., the vitamin D receptor gene). The candidate genes studied include the apolipoprotein $\mathrm{E}$ gene (APOE), the angiotensin-converting enzyme (ACE), the gene encoding angiotensinogen (AGT), angiotensin II type 1 receptor (AT1R) gene, G protein beta3 (GNB3), adducine gene, Cholesteryl Ester Transfer Protein (CETP), Hepatic Lipase, Phosphodiesterase 4D (PDE4D), ALOX5AP encoding 5-lipoxygenase activating protein, a polymorphism in the regulatory region of the Insulin-like Growth Factor 1 (IGF-1) gene, the hemochromatosis $(H F E)$ gene, Complement factor $\mathrm{H}$ gene $(\mathrm{CFH})$, and several polymorphisms in genes from the estrogen-, thyroid-, cortisol-, vitamin D-, IGF-, and Wntsignalling patways, the homocysteine pathway, and several matrix molecules.

\section{Genome wide association studies (GWAs)}

Genome Wide Association studies (GWAs) are based on genotyping epidemiological cohorts with ultra-high density SNP arrays with up to 1 million SNPs. The method has been shown to successfully identify common genetic factors for hundreds of traits and diseases (see www.genome.gov/ GWAstudies). Through a large grant from the Dutch research organisation NWO one of the world's largest GWAs datasets has been facilitated involving over 11,000 DNA samples from the Rotterdam Study cohorts. This GWAs dataset is based on the Illumina 550 and $610 \mathrm{~K}$ arrays and will be useful for all research lines within the Rotterdam Study. In addition, it will also serve as a control GWAs dataset for other research centers in and outside The Netherlands for both SNP frequencies as well as copy number variations (CNVs). In addition our group has also been active in developing new software for GWAs analyses [197].

New developments

The new development in the basic sciences will be to move to transciptomic studies and proteomic studies. With this view, the data collection protocol has been adjusted, standardizing blood collection. Further new developments 
target lipidomics and glycomic research. Other references may be found elsewhere [198-205].

\section{Pharmaco-epidemiologic studies}

\section{Objectives}

A major objective of the pharmaco-epidemiologic studies is to investigate the role of drugs as determinants of disease in the Rotterdam Study. This includes studying efficacy and effectiveness of drugs, as well as adverse reactions to drugs.

\section{Major findings}

Important findings have been published on pharmaco-epidemiological topics concerning the main outcomes in the Rotterdam Study. Studies about the association between dementia, and antihypertensive drugs [206] and NSAIDs [118] have strongly suggested a protective effect of both groups of drugs. Several studies have been performed on cardiovascular topics [207-209]. In one of these studies, NSAIDs were associated with an increased risk of heart failure. In line with the suspicion that QTc-prolonging drugs may cause sudden cardiac death, it was demonstrated in the Rotterdam Study that a prolonged QTc is indeed an important risk factor [208]. Furthermore, in one study it was demonstrated that high-dose corticosteroids increase the risk of atrial fibrillation [209]. In the important area of locomotor diseases, studies have demonstrated that thiazide diuretics protect against hip fracture [210] and that statins reduce the risk of vertebral fracture [211]. On the other hand, the risk that long-term use of certain NSAIDs may aggravate signs of osteoarthritis has been emphasized [212]. In the area of ophthalmic diseases, a protective effect of cholesterol-lowering agents on macular degeneration has been studied [139, 140]. In other areas, such as pharmacogenetics and other causes of interactions between drugs, several important findings have been published [192, 213-234].

\section{Methods update}

For several reasons, a drug is a highly attractive determinant in clinical epidemiologic research. First, drugs are probably the most important therapeutic intervention in health care. Despite rigorous clinical research before registration, many important effects of drugs are discovered after marketing. Second, all marketed drugs have proven biological activity, meaning that it concerns a determinant which really matters. Third, and as a consequence of the availability of complete medication histories in Dutch health care, the role of drug exposure can be assessed in a detailed way.
In the Rotterdam Study, there is an almost complete coverage of the population as of January 1, 1991, thanks to the fact that all pharmacies which serve the Ommoord district are on one computer network. To date, almost three million prescriptions have been delivered to the population of the Rotterdam Study and of each prescription, details are available about the product name and contents, ATC-code, dosage and duration of drug therapy.

Drugs are a group of determinants which can be studied in association with a large variety of diseases. In the Rotterdam Study there is a strong interest in the association between drugs and the cardiovascular, neurological, endocrine, and ophthalmic diseases which have been the main topics since its start. However, there is also important information about the association with psychiatric diseases, cancer, and chronic obstructive pulmonary disease. Moreover, important information about secondary outcomes, such as drug blood levels, other laboratory information, and information about hospital discharge diagnoses, is gathered on a continuous basis to facilitate pharmaco-epidemiological studies. Further EJE references can be found in [235-238].

\section{Management}

The Rotterdam Study is directed by a Management Team comprising Jan Heeringa, MD, PhD, study coordinator, Eric Neeleman, head IT, Frank van Rooij, MSc, head datamanagement, and the scientific principal investigators Albert Hofman (PI Rotterdam Study, chairman), Monique Breteler (PI Neurological diseases), Cornelia van Duijn (PI Genetic studies), Harry Janssen (PI Hepatic diseases), Gabriël Krestin (PI Radiology), Ernst Kuipers (PI Internal Medicine), Bruno Stricker (PI Pharmaco-epidemiology), Henning Tiemeier (PI Psychiatric diseases), André Uitterlinden (PI Genome wide analysis), Johannes Vingerling (PI Ophthalmic diseases) and Jacqueline Witteman (PI Cardiovascular diseases). The study of respiratory diseases is conducted in close collaboration with Prof Guy Brusselle, Department of Respiratory Medicine, University of Gent, Belgium.

Acknowledgments The Rotterdam Study is supported by the Erasmus Medical Center and Erasmus University Rotterdam, The Netherlands Organization for Scientific Research (NWO), The Netherlands Organization for Health Research and Development (ZonMw), the Research Institute for Diseases in the Elderly (RIDE), The Netherlands Genomics Initiative, the Ministry of Education, Culture and Science, the Ministry of Health, Welfare and Sports, the European Commission (DG XII), and the Municipality of Rotterdam. The contribution of inhabitants, general practitioners and pharmacists of the Ommoord district to the Rotterdam Study is gratefully acknowledged. The authors also gratefully acknowledge the contributions of previous principal investigators of the Rotterdam Study, including Frank van den Ouweland (Endocrine diseases), Diederick 
Grobbee (Cardiovascular diseases), Paulus de Jong (Ophthalmic diseases) and Huibert Pols (Endocrine diseases). The contribution of Guy Brusselle to the study of respiratory diseases is also gratefully acknowledged.

Open Access This article is distributed under the terms of the Creative Commons Attribution Noncommercial License which permits any noncommercial use, distribution, and reproduction in any medium, provided the original author(s) and source are credited.

\section{References}

1. Oeppen J, Vaupel JW. Broken limits to life expectancy. Science. 2002;296:1029-31.

2. Peto R, Doll R. There is no such thing as aging. BMJ. 1997; 315:1030-2.

3. Hofman A, Grobbee DE, de Jong PTVM, van den Ouweland FA. Determinants of disease and disability in the elderly: the Rotterdam Study. Eur J Epidemiol. 1991;7:403-22.

4. Hofman A, Breteler MMB, van Duijn CM, et al. The Rotterdam Study: objectives and design update. Eur J Epidemiol. 2007;22 (11):819-29.

5. Stang A. Appropriate epidemiologic methods as a prerequisite for valid study results. Eur J Epidemiol. 2008;23(12):761-5.

6. Drame M, Novella JL, Lang PO, et al. Derivation and validation of a mortality-risk index from a cohort of frail elderly patients hospitalised in medical wards via emergencies: the SAFES study. Eur J Epidemiol. 2008;23(12):783-91.

7. Jaddoe VWV, van Duijn CM, van der Heijden AJ, et al. The Generation R Study: design and cohort update until the age of 4 years. Eur J Epidemiol. 2008;23(12):801-11.

8. Jacobsen R, Oksuzyan A, Engberg H, et al. Sex differential in mortality trends of old-aged Danes: a nation wide study of age, period and cohort effects. Eur J Epidemiol. 2008;23(11):723-30.

9. Pekkanen J, Sunyer J. Problems in using incidence to analyze risk factors in follow-up studies. Eur J Epidemiol. 2008;23(9): $581-4$.

10. Danesh J, Hingorani A, Wensley F, et al. Collaborative pooled analysis of data on C-reactive protein gene variants and coronary disease: judging causality by Mendelian randomisation. Eur J Epidemiol. 2008;23(8):531-40.

11. Goodman A, Gatward R. Who are we missing? Area deprivation and survey participation. Eur J Epidemiol. 2008;23(6):397-487.

12. Matthiessen J, Biltoft-Jensen A, Rasmussen LB, et al. Comparison of the Danish physical activity questionnaire with a validated position and motion instrument. Eur $\mathrm{J}$ Epidemiol. 2008;23(5):311-22.

13. Larrieu S, Carcaillon L, Lefranc A, et al. Factors associated with morbidity during the 2003 heat wave in two population-based cohorts of elderly subjects: PAQUID and three city. Eur J Epidemiol. 2008;23(4):295-302.

14. Graff-Iversen S, Anderssen SA, Holme IM, et al. Two short questionnaires on leisure-time physical activity compared with serum lipids, anthropometric measurements and aerobic power in a suburban population from Oslo, Norway. Eur J Epidemiol. 2008;23(3):167-74

15. Stolk RP, Rosmalen JGM, Postma DS, et al. Universal risk factors for multifactorial diseases-lifelines: a three-generation population-based study. Eur J Epidemiol. 2008;23(1):67-74.

16. Menotti A, Lanti M, Kromhout D, et al. Forty-year coronary mortality trends and changes in major risk factors in the first 10 years of follow-up in the seven countries study. Eur J Epidemiol. 2007;22(11):747-54.
17. Koek HL, Kardaun JWPF, Gevers E, et al. Acute myocardial infarction incidence and hospital mortality: routinely collected national data versus linkage of national registers. Eur J Epidemiol. 2007;22(11):755-62.

18. Porta M, Pumarega J, Ferrer-Armengou O, et al. Timing of blood extraction in epidemiologic and proteomic studies: results and proposals from the PANKRAS II Study. Eur J Epidemiol. 2007;22(9):577-88.

19. Thelle DS. Assessment of physical activity and energy expenditure in epidemiological studies. Eur J Epidemiol. 2007;22(6): $351-2$.

20. Orsini N, Bellocco R, Bottai M, et al. Reproducibility of the past year and historical self-administered total physical activity questionnaire among older women. Eur J Epidemiol. 2007;22(6): 363-8.

21. Aadahl M, Kjaer M, Jorgensen T. Associations between overall physical activity level and cardiovascular risk factors in an adult population. Eur J Epidemiol. 2007;22(6):369-78.

22. Kurtze N, Rangul V, Hustvedt BE, et al. Reliability and validity of self-reported physical activity in the Nord-Trondelag health study (HUNT 2). Eur J Epidemiol. 2007;22(6):379-87.

23. Pitrou I, Dauchet L, Bailly L, et al. Mobile phone follow-up of subjects included in a prospective cohort study: unexpected difficulties. Eur J Epidemiol. 2007;22(6):411-2.

24. Alonso A, de Irala J, Martinez-Gonzalez MA. Representativeness, losses to follow-up and validity in cohort studies. Eur J Epidemiol. 2007;22(7):481-2.

25. Ekman A, Litton JE. New times, new needs; e-epidemiology. Eur J Epidemiol. 2007;22(5):285-92.

26. Ekman A, Klint A, Dickman PW, et al. Optimizing the design of web-based questionnaires-experience from a population-based study among 50, 000 women. Eur J Epidemiol. 2007;22(5):293.

27. Clarisse B, Nikasinovic L, Poinsard R, et al. The Paris prospective birth cohort study: which design and who participates? Eur J Epidemiol. 2007;22(3):203-10.

28. Kardys I, Deckers JW, Stricker BH, Vletter WB, Hofman A, Witteman JC. Echocardiographic parameters and all-cause mortality: The Rotterdam Study. Int J Cardiol. 2009;133(2): 198-204.

29. Kardys I, Vliegenthart R, Oudkerk M, Hofman A, Witteman JC. The female advantage in cardiovascular disease: do vascular beds contribute equally? Am J Epidemiol. 2007;166(4):403-12.

30. Mattace-Raso FUS, Sie MPS, van der Cammen TJM, Safar ME, Hofman A, Van Duijn CM, et al. Insertion//deletion gene polymorphism of the angiotensin-converting enzyme and blood pressure changes in older adults. The Rotterdam Study. J Hum Hypertens. 2007;21(9):736-40.

31. Koller MT, Steyerberg EW, Wolbers M, Stijnen T, Bucher HC, Hunink MG, et al. Validity of the Framingham point scores in the elderly: results from the Rotterdam Study. Am Heart J. 2007;154(1):87-93.

32. Elias-Smale SE, Kardys I, Oudkerk M, Hofman A, Witteman JC. C-reactive protein is related to extent and progression of coronary and extra-coronary atherosclerosis; results from the Rotterdam Study. Atherosclerosis. 2007;195(2):e195-202.

33. Bleumink GS, Knetsch AM, Sturkenboom MC, Straus SM, Hofman A, Deckers JW, et al. Quantifying the heart failure epidemic: prevalence, incidence rate, lifetime risk and prognosis of heart failure the Rotterdam Study. Eur Heart J. 2004;25:1614-9.

34. Heeringa J, van der Kuip DA, Hofman A, Kors JA, van Herpen $\mathrm{G}$, Stricker BH, et al. Prevalence, incidence and lifetime risk of atrial fibrillation: the Rotterdam Study. Eur Heart J. 2006;27: 949-53.

35. Van Vark LC, Kardys I, Bleumink GS, Knetsch AM, Deckers JW, Hofman A, et al. Lipoprotein-associated phospholipase A2 
activity and risk of heart failure: The Rotterdam Study. Eur Heart J. 2006;27:2346-52.

36. Heeringa J, Van der Kuip DA, Hofman H, Kors JA, Van Rooij FJ, Lip GY, et al. Subclinical atherosclerosis and risk of atrial fibrillation: the Rotterdam Study. Arch Intern Med. 2007;167:382-7.

37. Heeringa J, Kors JA, Hofman A, Van Rooij FJ, Witteman JC. Cigarette smoking and risk of atrial fibrillation: the Rotterdam Study. Am Heart J. 2008;156:1163-9.

38. Heeringa J, Hoogendoorn EH, Van der Deure WM, Hofman A, Peeters RP, Hop WC, et al. High-normal thyroid function and risk of atrial fibrillation: the Rotterdam Study. Arch Int Med. 2008;168:2219-24.

39. Dehghan A, Kardys I, De Maat MP, Uitterlinden AG, Sijbrands EJ, Bootsma $\mathrm{AH}$, et al. Genetic variation, C-reactive protein levels, and incidence of diabetes. Diabetes. 2007;56(3):872-8.

40. Dehghan A, Van Hoek M, Sijbrands EJ, Hofman A, Witteman JC. High serum uric acid as a novel risk factor for type 2 diabetes. Diabetes Care. 2008;31(2):361-2.

41. Dehghan A, Köttgen A, Yang Q, Hwang SJ, Kao WL, Rivadeneira $\mathrm{F}$, et al. Association of three genetic loci with uric acid concentration and high risk of gout: a genome-wide association study. Lancet. 2008;372(9654):1953-61.

42. Köttgen A, Glazer NL, Dehghan A, Hwang SJ, Katz R, Li M, et al. Multiple loci associated with indices of renal function and chronic kidney disease. Nat Genet. 2009;41:712-7.

43. Levy D, Ehret GB, Rice K, Verwoert GC, Launer LJ, Dehghan A, et al. Genome-wide association study of blood pressure and hypertension. Nat Genet. 2009;41:677-87.

44. Vasan RS, Glazer NL, Felix JF, Lieb W, Wild P, Felix SB, et al. Genetic variants associated with cardiac structure and function: a meta-analysis of genome-wide association data. JAMA. 2009;302(2):168-78.

45. Van der Meer IM, Bots ML, Hofman A, del Sol AI, van der Kuip DA, Witteman JC. Predictive value of noninvasive measures of atherosclerosis for incident myocardial infarction: the Rotterdam Study. Circulation. 2004;109:1089-94.

46. Vliegenthart R, Oudkerk M, Hofman A, Oei HHS, van Dijck W, van Rooij F, et al. Coronary calcification improves cardiovascular risk prediction in a population of older adults. Circulation. 2005;112:572-7.

47. Psaty BM, O’Donnell CJ, Gunadson V, Lunetta KL, Folsom AR, Rotter JI, et al. Design of prospective meta-analyses of genome-wide association studies from 5 cohorts. Circ Cardiovasc Genet. 2009;2:73-80.

48. Kardys I, De Maat MP, Uitterlinden AG, Hofman A, Witteman JC. C-reactive protein gene haplotypes and risk of coronary heart disease. The Rotterdam Study. Eur Heart J. 2006;27:1331-7.

49. Orsini N, Bellocco R, Bottai M, et al. Validity of self-reported total physical activity questionnaire among older women. Eur J Epidemiol. 2008;23(10):661-7.

50. Laszlo KD, Janszky I, Ahnve S. Income and recurrent events after a coronary event in women. Eur J Epidemiol. 2008;23(10): 669-80.

51. Reuser M, Bonneux L, Willekens F. The burden of mortality of obesity at middle and old age is small. A life table analysis of the US Health and Retirement Survey. Eur J Epidemiol. 2008;23(9):601-7.

52. McFadden E, Luben R, Wareham N, et al. Occupational social class, risk factors and cardiovascular disease incidence in men and women: a prospective study in the European prospective investigation of cancer and nutrition in Norfolk (EPIC-Norfolk) cohort. Eur J Epidemiol. 2008;23(7):449-58.

53. Hedlund E, Pehrsson K, Lange A, et al. Country of birth and survival after a first myocardial infarction in Stockholm, Sweden. Eur J Epidemiol. 2008;23(5):341-7.
54. Casiglia E, Schiavon L, Tikhonoff V, et al. Electrocardiographic criteria of left ventricular hypertrophy in general population. Eur J Epidemiol. 2008;23(4):261-71.

55. Gemes K, Ahnve S, Janszky I. Inflammation a possible link between economical stress and coronary heart disease. Eur J Epidemiol. 2008;23(2):95-103.

56. Zatonski W, Campos H, Willett W. Rapid declines in coronary heart disease mortality in Eastern Europe are associated with increased consumption of oils rich in alpha-linolenic acid. Eur $\mathbf{J}$ Epidemiol. 2008;23(1):3-10.

57. The Emerging Risk Factors Collaboration. Analysis of individual data on lipid, inflammatory and other markers in over 1.1 million participants in 104 prospective studies of cardiovascular diseases. Eur J Epidemiol. 2007;22(12):839-69.

58. Geleijnse JM, Witteman JCM, Stijnen T, et al. Sodium and potassium intake and risk of cardiovascular events and all-cause mortality: the Rotterdam Study. Eur J Epidemiol. 2007;22(11): 763-70.

59. Andriankaja OM, Genco RJ, Dorn J, et al. Periodontal disease and risk of myocardial infarction: the role of gender and smoking. Eur J Epidemiol. 2007;22(10):699-705.

60. Hyyppa MT, Maki J, Impivaara O, et al. Individual-level measures of social capital as predictors of all-cause and cardiovascular mortality: a population-based prospective study of men and women in Finland. Eur J Epidemiol. 2007;22(9):589-97.

61. Pischon T, Mohlig M, Hoffmann K, et al. Comparison of relative and attributable risk of myocardial infarction and stroke according to $\mathrm{C}$-reactive protein and low-density lipoprotein cholesterol levels. Eur J Epidemiol. 2007;22(7):429-38.

62. Sabour S, Rutten A, van der Schouw YT, et al. Inter-scan reproducibility of coronary calcium measurement using multi detector-row computed tomography (MDCT). Eur J Epidemiol. 2007;22(4):235-43.

63. Kuller LH. Can we learn more about the etiology of cardiovascular disease? Eur J Epidemiol. 2007;22(2):79-81.

64. Kabir Z, Bennett K, Critchley JA, et al. Can small changes in cardiovascular risk factors predict large future reductions in coronary heart disease mortality in Ireland? Eur J Epidemiol. 2007;22(2):83-9.

65. Danesh J, Saracci R, Berglund G, et al. EPIC-heart: the cardiovascular component of a prospective study of nutritional, lifestyle and biological factors in 520, 000 middle-aged participants from 10 European countries. Eur J Epidemiol. 2007; 22(2):129-41.

66. Spencer EA, Pirie KL, Stevens RJ, et al. Diabetes and modifiable risk factors for cardiovascular disease: the prospective Million Women Study. Eur J Epidemiol. 2008;23(12):793-9.

67. Prugger C, Wellmann J, Heidrich J, et al. Cardiovascular risk factors and mortality in patients with coronary heart disease. Eur J Epidemiol. 2008;23(11):731-7.

68. Odding E, Valkenburg HA, Stam HJ, Hofman A. Determinants of locomotor disability in people aged 55 years and over: the Rotterdam Study. Eur J Epidemiol. 2001;17(11):1033-41.

69. Tas U, Verhagen AP, Bierma-Zeinstra SM, Hofman A, Odding E, Pols HA, et al. Incidence and risk factors of disability in the elderly: the Rotterdam Study. Prev Med. 2007;44(3):272-8.

70. Van der Klift M, De Laet CE, McCloskey EV, Hofman A, Pols HA. The incidence of vertebral fractures in men and women: the Rotterdam Study. J Bone Miner Res. 2002;17(6):1051-6.

71. Schuit SC, van der Klift M, Weel AE, de Laet CE, Burger H, Seeman E, et al. Fracture incidence and association with bone mineral density in elderly men and women: the Rotterdam Study. Bone. 2004;34(1):195-202.

72. van Daele PL, Burger H, Algra D, Hofman A, Grobbee DE, Birkenhager JC, et al. Age-associated changes in ultrasound 
measurements of the calcaneus in men and women: the Rotterdam Study. J Bone Miner Res. 1994;9(11):1751-7.

73. van Daele PL, Seibel MJ, Burger H, Hofman A, Grobbee DE, van Leeuwen JP, et al. Case-control analysis of bone resorption markers, disability, and hip fracture risk: the Rotterdam study. BMJ. 1996;312(7029):482-3.

74. Goderie-Plomp HW, van der Klift M, de Ronde W, Hofman A, de Jong FH, Pols HA. Endogenous sex hormones, sex hormonebinding globulin, and the risk of incident vertebral fractures in elderly men and women: the Rotterdam Study. J Clin Endocrinol Metab. 2004;89(7):3261-9.

75. van Meurs JB, Dhonukshe-Rutten RA, Pluijm SM, van der Klift M, de Jonge R, Lindemans J, et al. Homocysteine levels and the risk of osteoporotic fracture. N Engl J Med. 2004;350(20):2033-41.

76. Bergink AP, Uitterlinden AG, Van Leeuwen JP, Hofman A, Verhaar JA, Pols HA. Bone mineral density and vertebral fracture history are associated with incident and progressive radiographic knee osteoarthritis in elderly men and women: the Rotterdam Study. Bone. 2005;37(4):446-56.

77. van der Klift M, de Laet CE, Coebergh JW, Hofman A, Pols HA. Bone mineral density and the risk of breast cancer: the Rotterdam Study. Bone. 2003;32(3):211-6.

78. van der Klift M, Pols HA, Hak AE, Witteman JC, Hofman A, de Laet CE. Bone mineral density and the risk of peripheral arterial disease: the Rotterdam Study. Calcif Tissue Int. 2002;70(6):443-9.

79. van Daele PL, Stolk RP, Burger H, Algra D, Grobbee DE, Hofman A, et al. Bone density in non-insulin-dependent diabetes mellitus. The Rotterdam Study. Ann Intern Med. 1995;122(6):409-14.

80. de Liefde II, van der Klift M, de Laet CE, van Daele PL, Hofman A, Pols HA. Bone mineral density and fracture risk in type-2 diabetes mellitus: the Rotterdam Study. Osteoporos Int. 2005;16(12):1713-20.

81. van der Klift M, de Laet CD, Pols HA. Assessment of fracture risk: who should be treated for osteoporosis? Best Pract Res Clin Rheumatol. 2005;19(6):937-50.

82. de Laet CE, van der Klift M, Hofman A, Pols HA. Osteoporosis in men and women: a story about bone mineral density thresholds and hip fracture risk. J Bone Miner Res. 2002;17(12):2231-6.

83. De Laet CE, Kanis JA, Oden A, Johanson H, Johnell O, Delmas $\mathrm{P}$, et al. Body mass index as a predictor of fracture risk: a metaanalysis. Osteoporos Int. 2005;16(11):1330-8.

84. Reijman M, Hazes JM, Bierma-Zeinstra SM, Koes BW, Christgau $\mathrm{S}$, Christiansen C, et al. A new marker for osteoarthritis: crosssectional and longitudinal approach. Arthritis Rheum. 2004; 50(8):2471-8.

85. Reijman M, Hazes JM, Pols HA, Bernsen RM, Koes BW, Bierma-Zeinstra SM. Validity and reliability of three definitions of hip osteoarthritis: cross sectional and longitudinal approach. Ann Rheum Dis. 2004;63(11):1427-33.

86. Reijman M, Hazes JM, Pols HA, Bernsen RM, Koes BW, Bierma-Zeinstra SM. Role of radiography in predicting progression of osteoarthritis of the hip: prospective cohort study. BMJ. 2005;330(7501):1183.

87. Brouwer GM, van Tol AW, Bergink AP, Belo JN, Bernsen RM, Reijman M, et al. Association between valgus and varus alignment and the development and progression of radiographic osteoarthritis of the knee. Arthritis Rheum. 2007;56(4):1204-11.

88. Dahaghin S, Bierma-Zeinstra SM, Reijman M, Pols HA, Hazes JM, Koes BW. Does hand osteoarthritis predict future hip or knee osteoarthritis? Arthritis Rheum. 2005;52(11):3520-7.

89. Hak AE, Pols HA, Stehouwer CD, Meijer J, Kiliaan JA, Hofman $\mathrm{A}$, et al. Markers of inflammation and cellular adhesion molecules in relation to insulin resistance in nondiabetic elderly: the Rotterdam Study. J Clin Endocrinol Metab. 2001;86(9):4398-405.

90. Kalmijn S, Mehta KM, Pols HA, Hofman A, Drexhage HA, Breteler MM. Subclinical hyperthyroidism and the risk of dementia. The Rotterdam Study. Clin Endocrinol (Oxf). 2000;53 (6):733-7.

91. Smit P, van Schaik RH, van der Werf M, van den Beld AW, Koper JW, Lindemans J, et al. A common polymorphism in the CYP3A7 gene is associated with a nearly 50\% reduction in serum dehydroepiandrosterone sulfate levels. J Clin Endocrinol Metab. 2005;90(9):5313-6.

92. Rivadeneira F, van Meurs JB, Kant J, Zillikens MC, Stolk L, Beck $\mathrm{TJ}$, et al. Estrogen receptor beta (ESR2) polymorphisms in interaction with estrogen receptor alpha (ESR1) and insulin-like growth factor I (IGF1) variants influence the risk of fracture in postmenopausal women. J Bone Miner Res. 2006;21(9):1443-56.

93. Rivadeneira F, Houwing-Duistermaat JJ, Beck TJ, Janssen JA, Hofman A, Pols HA, et al. The influence of an insulin-like growth factor I gene promoter polymorphism on hip bone geometry and the risk of nonvertebral fracture in the elderly: the Rotterdam Study. J Bone Miner Res. 2004;19(8):1280-90.

94. van Rossum EF, Koper JW, Huizenga NA, Uitterlinden AG, Janssen JA, Brinkmann AO, et al. A polymorphism in the glucocorticoid receptor gene, which decreases sensitivity to glucocorticoids in vivo, is associated with low insulin and cholesterol levels. Diabetes. 2002;51(10):3128-34.

95. den Heijer T, Schuit SC, Pols HA, van Meurs JB, Hofman A, Koudstaal PJ, et al. Variations in estrogen receptor alpha gene and risk of dementia, and brain volumes on MRI. Mol Psychiatry. 2004;9(12):1129-35.

96. Beck TJ, Ruff CB, Warden KE, Scott WW Jr, Rao GU. Predicting femoral neck strength from bone mineral data. A structural approach. Invest Radiol. 1990;25(1):6-18.

97. McCloskey EV, Spector TD, Eyres KS, Fern ED, O'Rourke N, Vasikaran S, et al. The assessment of vertebral deformity: a method for use in population studies and clinical trials. Osteoporos Int. 1993;3(3):138-47.

98. Forsen L, Berntsen GKR, Meyer HE, et al. Differences in precision in bone mineral density measured by SXA and DXA: the NOREPOS study. Eur J Epidemiol. 2008;23(9):615-24.

99. Ganry O, Lapotre-Ledoux B, Fardellone P, et al. Bone mass density, subsequent risk of colon cancer and survival in postmenopausal women. Eur J Epidemiol. 2008;23(7):467-73.

100. Yaegashi Y, Onoda T, Tanno K, et al. Association of hip fracture incidence and intake of calcium, magnesium, vitamin $\mathrm{D}$, and vitamin K. Eur J Epidemiol. 2008;23(3):219-25.

101. Siggeirsdottir K, Aspelund T, Sigurdsson G, et al. Inaccuracy in self-report of fractures may underestimate association with health outcomes when compared with medical record based fracture registry. Eur J Epidemiol. 2007;22(9):631-9.

102. Yang YJ, Wang YB, Lei SF, et al. AHSG gene polymorphisms are associated with bone mineral density in Caucasian nuclear families. Eur J Epidemiol. 2007;22(8):527-32.

103. Hong XM, Niu TH, Chen CZ, et al. Familial aggregation of forearm bone mineral density in Chinese. Eur J Epidemiol. 2007;22(5):335-41.

104. Piirtola M, Vahlberg T, Lopponen M, et al. Fractures as predictors of excess mortality in the aged-A population-based study with a 12-year follow-up. Eur J Epidemiol. 2007;23(11):747-55.

105. Hamaguchi M, Kojima T, Itoh Y, Harano Y, Fujii K, Nakajima $\mathrm{T}$, et al. The severity of ultrasonographic findings in nonalcoholic fatty liver disease reflects the metabolic syndrome and visceral fat accumulation. Am J Gastroenterol. 2007;102(12): 2708-15.

106. Sandrin L, Fourquet B, Hasquenoph JM, Yon S, Fournier C, Mal F, et al. Transient elastography: a new noninvasive method for assessment of hepatic fibrosis. Ultrasound Med Biol. 2003;29 (12):1705-13.

107. Talwalkar JA, Kurtz DM, Schoenleber SJ, West CP, Montori VM. Ultrasound-based transient elastography for the detection 
of hepatic fibrosis: systematic review and meta-analysis. Clin Gastroenterol Hepatol. 2007;5(10):1214-20.

108. Ott A, Breteler MMB, van Harskamp F, Claus JJ, van der Cammen TJM, Grobbee DE, et al. Prevalence of Alzheimer's disease and vascular dementia: association with education. The Rotterdam Study. BMJ. 1995;310:970-3.

109. de Rijk MC, Breteler MMB, Graveland GA, Ott A, Grobbee DE, van der Meché FGA, et al. Prevalence of Parkinson's disease in the elderly. The Rotterdam Study. Neurology. 1995;45:2143-6.

110. Ruitenberg A, Ott A, van Swieten JC, Hofman A, Breteler MMB. Incidence of dementia: does gender make a difference? Neurobiol Aging. 2001;22:575-80.

111. Hollander M, Koudstaal PJ, Bots ML, Grobbee DE, Hofman A, Breteler MMB. Incidence, risk and case fatality of first ever stroke in the elderly population. The Rotterdam Study. J Neurol Neurosurg Psychiatry. 2003;74:317-21.

112. de Lau LML, Giesbergen PCLM, de Rijk MC, Hofman A, Koudstaal PJ, Breteler MMB. Incidence of parkinsonism and Parkinson's disease in a general population: The Rotterdam Study. Neurology. 2004;63:1240-4.

113. Breteler MMB, Claus JJ, Grobbee DE, Hofman A. Cardiovascular disease and the distribution of cognitive function in an elderly population. The Rotterdam Study. BMJ. 1994;308:1604-8.

114. Hofman A, Ott A, Breteler MMB, Bots ML, Slooter AJC, van Harskamp F, et al. Atherosclerosis, apolipoprotein E and the prevalence of dementia and Alzheimer's disease in the Rotterdam Study. Lancet. 1997;349:151-4.

115. Ott A, Slooter AJC, Hofman A, van Harskamp F, Witteman JCM, van Broeckhoven C, et al. Smoking and risk of dementia and Alzheimer's disease in a population-based cohort study: the Rotterdam Study. Lancet. 1998;351:1840-3.

116. Engelhart MJ, Geerlings MI, Ruitenberg A, van Swieten JC, Hofman A, Witteman JCM, et al. Dietary intake of antioxidants and risk of Alzheimer's disease: the Rotterdam Study. JAMA. 2002;287:3223-9.

117. Ruitenberg A, van Swieten JC, Witteman JCM, Mehta KM, van Duijn CM, Hofman A, et al. Alcohol consumption and risk of dementia: the Rotterdam Study. Lancet. 2002;359:281-6.

118. In 't Veld BA, Ruitenberg A, Launer LJ, van Duijn CM, Hofman A, Stijnen Th, et al. NSAID and the risk of Alzheimer's disease or vascular dementia. The Rotterdam Study. New Engl J Med. 2001;345:1515-21.

119. Hollander M, Bots ML, Iglesias del Sol A, Koudstaal PJ, Witteman JCM, Grobbee DE, et al. Carotid plaques increase the risk of stroke and subtypes of cerebral infarction in asymptomatic elderly: The Rotterdam Study. Circulation. 2002;105: 2872-7.

120. Bos MJ, Schipper CMA, Koudstaal PJ, Witteman JCM, Hofman A, Breteler MM. High plasma C-reactive protein level is not an independent predictor for stroke. The Rotterdam Study. Circulation. 2006;114:1591-8.

121. Vermeer SE, den Heijer T, Prins ND, Hofman A, Koudstaal PJ, Breteler MMB. Silent brain infarcts and the risk of dementia and cognitive decline. The Rotterdam Scan Study. N Engl J Med. 2003;348:1215-22.

122. Vernooij MW, Ikram MA, Tanghe HL, Vincent AJ, Hofman A, Krestin GP, et al. Incidental findings on brain MRI in the general population. N Engl J Med. 2007;357:1821-8.

123. Vernooij MW, Ikram MA, Wielopolski PA, Krestin GP, Breteler MMB, van der Lugt A. Cerebral microbleeds: accelerated 3D T2*-weighted GRE MR imaging versus conventional 2D T2*weighted GRE MR imaging for detection. Radiology. 2008;248: 272-7.

124. Vernooij MW, van der Lugt A, Ikram MA, Wielopolski PA, Hofman A, Krestin GP, et al. Prevalence and risk factors of cerebral microbleeds. The Rotterdam Scan Study. Neurology. 2008;70:1208-14.

125. Greenberg SM, Vernooij MW, Cordonnier C, Viswanathan A, Al-Shahi Salman R, Warach W, et al. Cerebral microbleeds: A field guide to their detection and interpretation. Lancet Neurol. 2009;8:165-74.

126. Vernooij MW, De Groot M, Van der Lugt A, Ikram MA, Krestin GP, Hofman A, et al. White matter atrophy and lesion formation explain the loss of structural integrity of white matter in aging. NeuroImage. 2008;43:470-7.

127. Vernooij MW, Ikram MA, Vrooman HA, Wielopolski PA, Krestin GP, Hofman A, et al. White matter microstructural integrity and cognitive function in a general elderly population. Arch Gen Psych. 2009;66:545-53.

128. Breteler MMB, van Swieten JC, Bots ML, Grobbee DE, Claus JJ, van den Hout JHW, et al. Cerebral white matter lesions, vascular risk factors and cognitive function in a populationbased study. Neurology. 1994;44:1246-52.

129. de Groot JC, de Leeuw FE, Oudkerk M, Hofman A, Jolles J, Breteler MMB. Cerebral white matter lesions and depressive symptoms in elderly adults. Arch Gen Psychiat. 2000;57:1071-6.

130. Vingerling JR, Dielemans I, Hofman A, et al. The prevalence of age-related maculopathy in the Rotterdam Study. Ophthalmology. 1995;102:205-10.

131. Klaver CC, Wolfs RC, Vingerling JR, Hofman A, de Jong PT. Age-specific prevalence and causes of blindness and visual impairment in an older population: the Rotterdam Study. Arch Ophthalmol. 1998;116:653-8.

132. Vingerling JR, Hofman A, Grobbee DE, de Jong PT. Age-related macular degeneration and smoking. The Rotterdam Study. Arch Ophthalmol. 1996;114:1193-6.

133. Klaver CC, Assink JJ, Vingerling JR, Hofman A, de Jong PT. Smoking is also associated with age-related macular degeneration in persons aged 85 years and older: The Rotterdam Study. Arch Ophthalmol. 1997;115:945.

134. Vingerling JR, Dielemans I, Bots ML, Hofman A, Grobbee DE, de Jong PT. Age-related macular degeneration is associated with atherosclerosis. The Rotterdam Study. Am J Epidemiol. 1995; 142:404-9.

135. Ikram MK, van Leeuwen R, Vingerling JR, Hofman A, de Jong PT. Relationship between refraction and prevalent as well as incident age-related maculopathy: the Rotterdam Study. Invest Ophthalmol Vis Sci. 2003;44:3778-82.

136. Klaver CC, Kliffen M, van Duijn CM, et al. Genetic association of apolipoprotein $\mathrm{E}$ with age-related macular degeneration. Am J Hum Genet. 1998;63:200-6.

137. Klaver CC, Wolfs RC, Assink JJ, van Duijn CM, Hofman A, de Jong PT. Genetic risk of age-related maculopathy. Populationbased familial aggregation study. Arch Ophthalmol. 1998;116: 1646-51.

138. Assink JJ, Klaver CC, Houwing-Duistermaat JJ, et al. Heterogeneity of the genetic risk in age-related macular disease: a population-based familial risk study. Ophthalmology. 2005;112:482-7.

139. van Leeuwen R, Vingerling JR, de Jong PT. Risk of macular degeneration with statin use should be interpreted with caution. BMJ. 2001;323:1308.

140. van Leeuwen R, Vingerling JR, Hofman A, de Jong PT, Stricker $\mathrm{BH}$. Cholesterol lowering drugs and risk of age related maculopathy: prospective cohort study with cumulative exposure measurement. BMJ. 2003;326:255-6.

141. van Leeuwen R, Boekhoorn S, Vingerling JR, et al. Dietary intake of antioxidants and risk of age-related macular degeneration. JAMA. 2005;294:3101-7.

142. Boekhoorn SS, Vingerling JR, Hofman A, de Jong PT. Alcohol consumption and risk of aging macula disorder in a general 
population: the Rotterdam Study. Arch Ophthalmol. 2008;126: 834-9.

143. Despriet DD, Klaver CC, Witteman JC, et al. Complement factor $\mathrm{H}$ polymorphism, complement activators, and risk of agerelated macular degeneration. JAMA. 2006;296:301-9.

144. Boekhoorn SS, Vingerling JR, Witteman JC, Hofman A, de Jong PT. C-reactive protein level and risk of aging macula disorder: The Rotterdam Study. Arch Ophthalmol. 2007;125:1396-401.

145. Boekhoorn SS, Isaacs A, Uitterlinden AG, et al. Polymorphisms in the vascular endothelial growth factor gene and risk of agerelated macular degeneration: the Rotterdam Study. Ophthalmology. 2008;115:1899-903.

146. Ho L, Boekhoorn SS, Liana, et al. Cataract surgery and the risk of aging macula disorder: the Rotterdam Study. Invest Ophthalmol Vis Sci. 2008;49:4795-800.

147. Ho L, Witteman JC, Rohrer B, Hofman A, de Jong PT, Vingerling JR. Lipoprotein-associated phospholipase A2 and risk of age-related macular degeneration: the Rotterdam Study. Arch Ophthalmol. 2009;127:340-1.

148. de Voogd S, Ikram MK, Wolfs RC, Jansonius NM, Hofman A, de Jong PT. Incidence of open-angle glaucoma in a general elderly population: the Rotterdam Study. Ophthalmology. 2005;112: 1487-93.

149. Ikram MK, de Jong FJ, Vingerling JR, et al. Are retinal arteriolar or venular diameters associated with markers for cardiovascular disorders? The Rotterdam Study. Invest Ophthalmol Vis Sci. 2004;45:2129-34.

150. Ikram MK, de Jong FJ, Bos MJ, et al. Retinal vessel diameters and risk of stroke: the Rotterdam Study. Neurology. 2006;66: 1339-43.

151. Ikram MK, De Jong FJ, Van Dijk EJ, et al. Retinal vessel diameters and cerebral small vessel disease: the Rotterdam Scan Study. Brain. 2006;129:182-8.

152. Ikram MK, Janssen JA, Roos AM, et al. Retinal vessel diameters and risk of impaired fasting glucose or diabetes: the Rotterdam Study. Diabetes. 2006;55:506-10.

153. Ikram MK, Witteman JC, Vingerling JR, Breteler MM, Hofman A, de Jong PT. Retinal vessel diameters and risk of hypertension: the Rotterdam Study. Hypertension. 2006;47:189-94.

154. Bird AC, Bressler NM, Bressler SB, et al. An international classification and grading system for age-related maculopathy and age-related macular degeneration. The International ARM Epidemiological Study Group. Surv Ophthalmol. 1995;39: 367-74.

155. Luijendijk HJ, van den Berg JF, Dekker MJHJ, van Tuijl HR, Otte W, Smit F, et al. Incidence and recurrence of late-life depression. Arch Gen Psychiat. 2008;65:1394-401.

156. Tiemeier H, van Dijck W, Hofman A, Witteman JCM, Stijnen T, Breteler MMB. Atherosclerosis and late life depression are related. The Rotterdam Study. Arch Gen Psychiat. 2004;61: 369-76.

157. Tiemeier H, van Tuijl HR, Hofman A, Kiliaan AJ, Breteler MMB. Plasma fatty acid composition and depression in the elderly are associated: The Rotterdam Study. Am J Clin Nutr. 2003;78:40-6.

158. Naarding P, Tiemeier H, Breteler MM, Schoevers RA, Jonker C, Koudstaal PJ, et al. Clinically defined vascular depression in the general population. Psychol Med. 2007;37:383-92.

159. van den Berg JF, Knvistingh Neven A, Tulen JH, Hofman A, Witteman JC, Miedema HM, et al. Actigraphic sleep duration and fragmentation are related to obesity in the elderly: the Rotterdam Study. Int J Obes. 2008;32:1083-90.

160. van den Berg JF, Miedema HM, Tulen JH, Neven AK, Hofman A, Witteman JC, et al. Long sleep duration is associated with serum cholesterol in the elderly: the Rotterdam Study. Psychosom Med. 2008;70:1005-11.
161. Van der Berg JF, Luijendijk HJ, Tulen JH, Hofman A, Neven AK, Tiemeier H. Sleep in depression and anxiety disorders: a population-based study of elderly persons. J Clin Psychiatry. 2009. doi: $10.4088 / \mathrm{JCP} .08 \mathrm{~m} 04448$

162. Omidvar M, Stolk L, Uitterlinden AG, Hofman A, Van Duijn $\mathrm{CM}$, Tiemeier H. The effect of catechol-O-methyltransferase Met/Val functional polymorphism on smoking cessation: retrospective and prospective analyses in a cohort study. Pharmacogenet Genomics. 2009;19:45-51.

163. Tiemeier H, Schuit SC, den Heijer T, van Meurs JB, van Tuijl HR, Hofman A, et al. Estrogen receptor alpha gene polymorphisms and anxiety disorder in an elderly population. Mol Psychiatry. 2005;10:806-7.

164. Tiemeier H, van Tuijl HR, Hofman A, Meijer J, Kiliaan AJ, Breteler MMB. Vitamin B12, folate, and homocysteine in depression: the Rotterdam Study. Am J Psychiatry. 2002;159: 2099-101.

165. Tiemeier H, Hofman A, Kiliaan AJ, Meijer J, Breteler MMB. Vitamin E and depressive symptoms are not related. The Rotterdam Study. J Affect Disord. 2002;72:79-83. 162.

166. Dekker MJ, Koper JW, van Aken MO, Pols HA, Hofman A, de Jong FH, et al. Salivary cortisol is related to atherosclerosis of carotid arteries. J Clin Endocrinol Metab. 2008;93:3741-7.

167. Ikram MA, Luijendijk HJ, Vernooij MW, Hofman A, Niessen WJ, van der Lugt A, Tiemeier H, Breteler MMB. Structural markers of vascular brain disease in relation to depression in the elderly. Epidemiology (in press).

168. Bos MJ, Lindén T, Koudstaal PJ, Hofman A, Skoog I, Breteler MMB, et al. Depressive symptoms and risk of stroke: The Rotterdam Study. J Neurol Neurosurg Psychiat. 2008;79: 997-1001.

169. Wing JK, Babor T, Brugha T, Burke J, Cooper JE, Giel R. Scan: schedules for clinical assessment in neuropsychiatry. Arch Gen Psychiatry. 1990;47:589-93.

170. Wittchen HU, Lachner G, Wunderlich U, Pfister H. Test-retest reliability of the computerized DSM-IV version of the Munichcomposite international diagnostic interview (M-CIDI). Soc Psychiatry Psychiatr Epidemiol. 1998;33:568-78.

171. van den Berg JF, van Rooij FJ, Vos H, Tulen JH, Hofman A, Miedema HM, et al. Disagreement between subjective and actigraphic measures of sleep duration in a population-based study of elderly persons. J Sleep Res. 2008;17:295-302.

172. Prigerson HG, Maciejewski PK, Reynolds CF III, Bierhals AJ, Newsom JT, Fasiczka A, et al. Inventory of complicated grief: a scale to measure maladaptive symptoms of loss. Psychiatry Res. 1995;59:65-79.

173. van Durme YM, Verhamme KM, Stijnen T, van Rooij FJ, Van Pottelberge GR, Hofman A, et al. Prevalence, incidence, and lifetime risk for the development of COPD in the elderly: the Rotterdam Study. Chest. 2009;135:368-77.

174. Lopez AD, Mathers CD, Ezzati M, Jamison DT, Murray CJ. Global and regional burden of disease and risk factors, 2001: systematic analysis of population health data. Lancet. 2006;367: 1747-57.

175. van Durme YM, Verhamme KM, Aarnoudse AJ, Van Pottelberge GR, Hofman A, Witteman JC, et al. C-reactive protein levels, haplotypes, and the risk of incident chronic obstructive pulmonary disease. Am J Respir Crit Care Med. 2009;179:375-82.

176. Macintyre N, Crapo RO, Viegi G, Johnson DC, van der Grinten $\mathrm{CP}$, Brusasco V, et al. Standardisation of the single-breath determination of carbon monoxide uptake in the lung. Eur Respir J. 2005;26:720-35.

177. Duijts L, Jaddoe VWV, Hofman A, et al. Maternal smoking in prenatal and early postnatal life and the risk of respiratory tract infections in infancy. The generation R study. Eur J Epidemiol. 2008;23(8):547-55. 
178. Lawlor DA, Cooper AR, Bain C, et al. Associations of birth size and duration of breast feeding with cardiorespiratory fitness in childhood: findings from the Avon longitudinal study of parents and children (ALSPAC). Eur J Epidemiol. 2008;23(6):411-22.

179. Kompauer I, Demmelmair H, Koletzko B, et al. Association of fatty acids in serum phospholipids with lung function and bronchial hyperresponsiveness in adults. Eur J Epidemiol. 2008;23(3): 175-90.

180. de Luise C, Brimacombe M, Pedersen L, et al. Chronic obstructive pulmonary disease and mortality following hip fracture: a population-based cohort study. Eur J Epidemiol. 2008;23(2):115-22.

181. Hugg T, Ruotsalainen R, Jaakkola MS, et al. Comparison of allergic diseases, symptoms and respiratory infections between Finnish and Russian school children. Eur J Epidemiol. 2008;23(2):123-33.

182. Rzehak P, Schoefer Y, Wichmann HE, et al. A prospective study on the association between hay fever among children and incidence of asthma in East Germany. Eur J Epidemiol. 2008;23(1): $17-22$.

183. Svartberg J, Schirmer H, Medbo A, et al. Reduced pulmonary function is associated with lower levels of endogenous total and free testosterone. The Tromso Study. Eur J Epidemiol. 2007;22 (2):107-12.

184. Moreno T, Querol X, Alastuey A, et al. Airborne particulate matter and premature deaths in urban Europe: the new WHO guidelines and the challenge ahead as illustrated by SpainCommentary. Eur J Epidemiol. 2007;22(1):1-5.

185. van Meurs JB, Dhonukshe-Rutten RA, Pluijm SM, van der Klift $\mathrm{M}$, de Jonge R, Lindemans $\mathrm{J}$, et al. Homocysteine levels and the risk of osteoporotic fracture. N Engl J Med. 2004;350:2033-41.

186. Vaessen N, Janssen JA, Heutink P, Hofman A, Lamberts SW, Oostra BA, et al. Association between genetic variation in the gene for insulin-like growth factor-I and low birthweight. Lancet. 2002;359:1036-7.

187. van Meurs JBJ, Schuit SCE, Weel AEAM, van der Klift M, Bergink AP, Arp PP, et al. Association of $5^{\prime}$ estrogen recptor alpha gene polymorphisms with bone mineral density, vertebral bone area, and fracture risk. Hum Molec Genet. 2003;12:1745-54.

188. Schuit SC, Oei HH, Witteman JC, Geurts van Kessel CH, van Meurs JB, Nijhuis RL, et al. Estrogen receptor alpha gene polymorphisms and risk of myocardial infarction. JAMA. 2004; 291:2969-77.

189. Ioannidis JP, Gwinn M, Little J, Higgins JP, Bernstein JL, Boffetta $\mathrm{P}$, et al. Human genome epidemiology network and the network of investigator networks. A roadmap for efficient and reliable human genome epidemiology. Nat Genet. 2006;38(1):3-5.

190. Ioannidis JPA, Ralston SH, Bennett ST, Brandi ML, Grinberg D, Karassa FB, et al. Large-scale evidence for differential genetic effects of ESR1 polymorphisms on osteoporosis outcomes: The GENOMOS Study. JAMA. 2004;292(17):2105-14.

191. Uitterlinden AG, Ralston SH, Brandi ML, Carey AH, Grinberg $\mathrm{D}$, Langdahl BL, et al. Large-scale analysis of association between common vitamin $\mathrm{D}$ receptor gene variations and osteoporosis: the GENOMOS study. Ann Int Medicine. 2006;145 (4):255-64.

192. Aarnoudse AJLHJ, Newton-Cheh C, de Bakker PIW, Straus SMJM, Kors JA, Hofman A, et al. A common NOS1AP variant is associated with longer QTc interval and sudden cardiac death: the Rotterdam Study. Circulation. 2007;116:10-6.

193. Fang Y, van Meurs JB, d'Alesio A, Jhamai M, Zhao H, Rivadeneira F, et al. Promoter and $3^{\prime}$ UTR haplotypes in the vitamin D receptor gene predispose to osteoporotic fracture: the Rotterdam Study. Am J Hum Genet. 2005;77(5):807-23.

194. Willer CJ, Speliotes EK, Loos RJF, Li S, Lindgren CM, Heid IM, et al. Six new loci associated with body mass index highlight a neural influence on body weight regulation. Nat Genet. 2009;41:25-34.
195. Prokopenko I, Langenberg C, Florez JC, Saxena R, Soranzo N, Thorleifsson $\mathrm{G}$, et al. Variants in the melatonin receptor $1 \mathrm{~B}$ gene (MTNR1B) influence fasting glucose levels. Nat Genet. 2009; 4191:77-81.

196. Aulchenko YS, Ripatti S, Lindqvist I, Boomsma D, Heid IM, Pramstaller PP, et al. Loci influencing lipid levels and coronary heart disease risk in 16 European population cohorts. Nat Genet. 2009;41:47-55.

197. Aulchenko YS, Ripke S, Isaacs A, van Duijn CM. GenABEL: an $\mathrm{R}$ library for genome-wide association analysis. Bioinformatics. 2007;23(10):1294-6.

198. Lei L, Ye LN, Liu H, et al. Passive smoking, cytochrome P450 gene polymorphisms and dysmenorrhea. Eur J Epidemiol. 2008; 23(7):475-81.

199. Mao RF, Fan YH, Chen F, et al. Genetic polymorphism of MTHFR G1793A in Chinese populations. Eur J Epidemiol. 2008; 23(5):363-8.

200. Seabra AF, Mendonca DM, Goring HHH, et al. Genetic and environmental factors in familial clustering in physical activity. Eur J Epidemiol. 2008;23(3):205-11.

201. Porta M, Pumarega J, Ferrer-Armengou O, et al. Timing of blood extraction in epidemiologic and proteomic studies: results and proposals from the PANKRAS II Study. Eur J Epidemiol. 2007;22:577-88.

202. Jaddoe VWV, Bakker R, van Duijn CM, et al. The Generation R Study Biobank: a resource for epidemiological studies in children and their parents. Eur J Epidemiol. 2007;22(12):917-23.

203. Isaacs A, Sayed-Tabatabaei FA, Aulchenko YS, et al. Heritabilities, apolipoprotein $\mathrm{E}$, and effects of inbreeding on plasma lipids in a genetically isolated population: The Erasmus Rucphen Family Study. Eur J Epidemiol. 2007;22(2):99-105.

204. De Moor MHM, Stubbe JH, Boomsma DI, et al. Exercise participation and self-rated health: do common genes explain the association? Eur J Epidemiol. 2007;22(1):27-32.

205. Janssens ACJW. Is it the time right for translation research in genomics? Eur J Epidemiol. 2008;23(11):707-10.

206. In 't Veld BA, Ruitenberg A, Hofman A, Stricker BHCh, Breteler MMB. Antihypertensive drugs and incidence of dementia: the Rotterdam Study. Neurobiol Aging. 2001;22:407-12.

207. Feenstra J, Heerdink ER, Grobbee DE, Stricker BHCh. Association of nonsteroidal anti-inflammatory drugs with first occurrence of heart failure and with relapsing heart failure. Arch Int Med. 2002;162:265-70.

208. Straus SM, Kors JA, de Bruin ML, van der Hooft CS, Hofman A, Heeringa $J$, et al. Prolonged QTc interval and risk of sudden cardiac death in a population of older adults. J Am Coll Cardiol. 2006;47:362-7.

209. Van der Hooft CS, Heeringa J, Brusselle GG, Hofman A, Witteman JCM, Kingma JH, et al. Corticosteroids and the risk of atrial fibrillation. Arch Int Med. 2006;165:1016-20.

210. Schoofs MWCJ, van der Klift M, Hofman A, de Laet CEDH, Herings RMC, Stijnen Th, et al. Thiazide diuretics and the risk for hip fracture. Ann Intern Med. 2003;139:476-82.

211. Schoofs MW, Sturkenboom MCJM, van der Klift M, Hofman A, Pols HA, Stricker BHCh. HMG-CoA reductase inhibitors and the risk of vertebral fracture. J Bone Miner Res. 2004;19:1525-30.

212. Reijman M, Bierma-Zeinstra SM, Pols HAP, Koes BW, Stricker BHCh, Hazes JM. Is there an association between the use of different types of NSAIDs and radiologic progression of osteoarthritis? The Rotterdam Study. Arthritis Rheum. 2005;52:3137-42.

213. Visser LE, Penning-van Beest FJA, Kasbergen AAH, De Smet PAGM, Vulto AG, Hofman A, et al. Overanticoagulation associated with combined use of antifungal agents and coumarin anticoagulants. Clin Pharmacol Ther. 2002;71:496-502.

214. Visser LE, Penning-van Beest FJA, Kasbergen HAA, De Smet PAGM, Vulto AG, Hofman A, et al. Overanticoagulation 
associated with combined use of antibacterial agents and acenocoumarol or phenprocoumon anticoagulants. Thromb Haemost. 2002;88:705-10.

215. Visser LE, van Vliet M, van Schaik RHN, Kasbergen AAH, de Smet PAGM, Vulto AG, et al. The risk of overanticoagulation in patients with cytochrome $\mathrm{P} 450 \mathrm{CYP} 2 \mathrm{C} 9 * 2$ or CYP2C $9 * 3$ alleles on acenocoumarol or phenprocoumon. Pharmacogenetics. 2004;14:27-33.

216. Visser LE, Penning-van Beest FJ, Wilson JHP, Vulto AG, Kasbergen AA, de Smet PAGM, et al. Overanticoagulation associated with combined use of lactulose and coumarin anticoagulants. Br J Clin Pharmacol. 2004;57:522-4.

217. Visser LE, van Schaik RH, van Vliet M, Trienekens PH, de Smet PAGM, Vulto AG, et al. The risk of bleeding complications in patients with cytochrome P450 CYP2C9*2 or CYP2C9*3 alleles on acenocoumarol or phenprocoumon. Thromb Haemost. 2004; 92:61-6.

218. Visser LE, Bleumink GS, Trienekens PH, Vulto AG, Hofman A, Stricker BHCh. The risk of overanticoagulation in patients with heart failure on coumarin anticoagulants. Br J Haematol. 2004; 127:85-9.

219. Visser LE, van Schaik RHN, van Vliet M, Trienekens PH, de Smet PAGM, Vulto AG, et al. Allelic variants of cytochrome P450 2C9 modify the interaction between nonsteroidal anti-inflammatory drugs and coumarin anticoagulants. Clin Pharmacol Ther. 2005; 77:479-85.

220. Bleumink GS, Schut AF, Sturkenboom MC, van Duijn CM, Deckers JW, Hofman A, et al. Mortality in patients with hypertension on ACE-inhibitor treatment is influenced by the ACE I/D polymorphism. Pharmacogenet Genomics. 2005;15: $75-81$.

221. Visser LE, Trienekens PH, de Smet PAGM, Vulto AG, Hofman A, van Duijn CM, et al. Patients with an ApoE epsilon4 allele require lower doses of coumarin anticoagulants. Pharmacogenet Genomics. 2005;15:69-74.

222. Schelleman H, Klungel OH, Witteman JCM, Hofman A, van Duijn CM, de Boer A, et al. The influence of the alpha-adducin G460W polymorphism and angiotensinogen M235T polymorphism on antihypertensive medication and blood pressure. Eur $\mathbf{J}$ Hum Gen. 2006;14:860-6.

223. Schelleman H, Klungel OH, van Duijn CM, Witteman JCM, Hofman A, de Boer A, et al. Drug-gene interaction between the insertion/deletion polymorphism of the angiotensin-converting enzyme gene and antihypertensive therapy. Ann Pharmacother. 2006;40:212-8.

224. Becker ML, Visser LE, Tirnekens PH, Hofman A, van Schaik $\mathrm{RH}$, Stricker BHCh. Cytochrome $\mathrm{P} 4502 \mathrm{C} 9 * 2$ and $* 3$ polymorphisms and the dose and effect of sulphonylurea in type II diabetes mellitus. Clin Pharmacol Ther. 2008;83:288-92.

225. Visser LE, van Schaik RH, Danser JAH, Hofman A, Witteman JCM, van Duijn CM, et al. The risk of myocardial infarction in patients with reduced activity of cytochrome P450 2C9. Pharmacogen Genomics. 2007;17:473-9.

226. Schelleman H, Klungel OH, Witteman JCM, Breteler MMB, Yazdanpanah M, Danser AH, et al. Angiotensinogen M235T polymorphism and the risk of myocardial infarction and stroke among hypertensive patients on ACE-inhibitors or beta-blockers. Eur J Hum Genet. 2007;15:478-84.

227. Schelleman H, Klungel OH, Witteman JCM, Hofman A, van Duijn CM, de Boer A, et al. Pharmacogenetic interactions of three candidate gene polymorphisms with ACE-inhibitors or beta-blockers and the risk of atherosclerosis. Br J Clin Pharmacol. 2007;64:57-66.

228. Schelleman H, Klungel OH, Witteman JCM, Breteler MMB, Hofman A, van Duijn CM, et al. Diuretic-gene interaction and the risk of myocardial infarction and stroke. Pharmacogenomics J. 2007;7:346-52.

229. Aarnoudse AJ, Dieleman JP, Visser LE, Arp PP, van der Heiden IP, van Schaik RH, et al. Common ATP-binding cassette B1 variants are associated with increased digoxin serum concentration. Pharmacogenet Genomics. 2008;18:299-305.

230. Teichert M, Visser LE, van Schaik RH, Hofman A, Uitterlinden AG, De Smet PA, et al. Vitamin K epoxide reductase complex subunit 1 (VKORC1) polymorphism and aortic calcification: the Rotterdam Study. Arterioscler Thromb Vasc Biol. 2008;28:771-6.

231. Bijl MJ, Visser LE, Hofman A, Vulto AG, van Gelder T, Stricker BHCh, et al. Influence of the CYP2D6*4 polymorphism on dose, switching, and discontinuation of antidepressants. Br J Clin Pharmacol. 2008;65:558-64.

232. Becker ML, Visser LE, Newton-Cheh C, Witteman JC, Hofman A, Uitterlinden AG, et al. Genetic variation in the NOS1AP gene is associated with the incidence of diabetes mellitus in users of calcium channel blockers. Diabetologia. 2008;51:2138-40.

233. Becker ML, Aarnoudse AJ, Newton-Cheh C, Hofman A, Witteman JC, Uitterlinden AG, et al. Common variation in the NOS1AP gene is associated with reduced glucose-lowering effect and with increased mortality in users of sulfonylurea. Pharmacogenet Genomics. 2008;18:591-7.

234. Bijl M, Visser L, van Schaik R, Kors J, Witteman J, Hofman A, et al. Genetic variation in the CYP2D6 gene is associated with a lower heart rate and blood pressure in beta-blocker users. Clin Pharmacol Ther. 2009;85(1):45-50.

235. Davis S, Mirick DK. Medication use and the risk of breast cancer. Eur J Epidemiol. 2007;22(5):319-25.

236. de Luise C, Lanes SF, Jacobsen J, et al. Cardiovascular and respiratory hospitalizations and mortality among users of tiotropium in Denmark. Eur J Epidemiol. 2007;22(4):267-72.

237. Gouya G, Reichardt B, Ohrenberger G, et al. Survival of patients discharged after acute myocardial infarction and evidence-based drug therapy. Eur J Epidemiol. 2007;22(3):145-9.

238. Osterbrand M, Fahlen M, Oden A, et al. A method to predict the metabolic effects of changes in insulin treatment in subgroups of a large population based patient cohort. Eur J Epidemiol. 2007; 22(3):151-7.

239. Hak AE, Pols HAP, Visser TJ, Drexhage HA, Hofman A, Witteman JCM. Subclinical hypothyroidism is an independent risk factor for atherosclerosis and myocardial infarction in elderly women: the Rotterdam Study. Ann Intern Med. 2000;132:270-8.

240. Uccelli R, Binazzi A, Altavista P, et al. Geographic distribution of amyotrophic lateral sclerosis through motor neuron disease mortality data. Eur J Epidemiol. 2007;22(11):781-90.

241. Landes M, Thorne M, Barlow P, et al. Prevalence of sexually transmitted infections in HIV-1 infected pregnant women in Europe. Eur J Epidemiol. 2007;22:1925-36.

242. Lang PO, Meyer N, Heitz D, et al. Loss of independence in Katz's ADL ability in connection with an acute hospitalization: early clinical markers in French older people. Eur J Epidemiol. 2007;22(9):621-30. 